\title{
SOME OBJECTIVE METHODS FOR DETERMINING RELATIVE IMPORTANCE OF FINANCIAL RATIOS
}

\author{
G. Anupama \\ Part time PhD Scholar, Department of Mechanical Engineering, \\ College of Engineering (A), Andhra University, Visakhapatnam, India \\ V.V.S. Kesava Rao \\ Professor, Department of Mechanical Engineering, \\ College of Engineering (A), Andhra University, Visakhapatnam, India
}

\begin{abstract}
The segregation of financial ratios into input and output ratios are useful to determine the business insolvency/failure and financial efficiency of the business organizations. A total of 18 software companies are considered with nine financial ratios. The aim of this study is to examine the efficiency of various financial ratios and identify their average weights through objective methods namely MLP of Artificial Neural Network, Entropy and Critic Methods.
\end{abstract}

Key word: MLP, Entropy, Critic Methods.

Cite this Article: G. Anupama and V.V.S. Kesava Rao, Some Objective Methods for Determining Relative Importance of Financial Ratios, International Journal of Management, 10 (4), 2019, pp. 76-96.

$\mathrm{http}: / /$ iaeme.com/Home/issue/IJM?Volume $=10 \&$ Issue $=4$

\section{INTRODUCTION}

Financial ratio analysis is much popular among regulators due to its effectiveness in different countries including India, this method could not import the weights to the financial ratios to evaluate the performance of business organizations. Multi-criteria decision making methods consider the relative weights of financial ratios to evaluate the performance of business organizations.

The weights of criteria are usually assigned by the DMs, based on their own experiences, knowledge and perception of the problem. However, the DMs involved in the decision process usually have different attitudes and can rarely reach an agreement on the relative importance of criteria. Another difficulty is the inconsistency problem in subjective weighting. These problems can be overcome by using an objective weighting process, which is carried out independently from the subjective preferences of the DMs. The logic behind such a weighting process is that each alternative is objectively described by its performance scores, and these scores in the performance matrix represent the sources of information provided to the DM. 
In Entropy Method (EM), the criteria weights are obtained directly from the performance matrix, i.e., independently of the DM. This qualifies the entropy method (EM) as an unbiased evaluation procedure. In addition to the entropy method, any other method of measuring the divergence in performance ratings can be used to determine the objective weights. Diakoulaki et al. (1995) has proposed the CRITIC (CRiteria Importance Through Inter-criteria Correlation) method.

One interesting area for the use of neural networks is in event prediction. This study develops a neural network model for determination of relative weights of predictor variables using financial data from the organizations. Relative importance of input variables in neural networks is computed as the sum of the product of raw input-hidden, hidden-output connection weights, proposed by Olden et al. 2004.

\subsection{Stockholders' equity ratio (FR1)}

The ratio is expressed as a percentage and is calculated by dividing a company's total shareholder equity by its total assets.

\subsection{Turnover rate of accounts receivable (Debtor Turnover Ratio) (FR2)}

Receivables turnover ratio can be calculated by dividing the net value of credit sales during a given period by the average accounts receivable during the same period = net value of credit sales/average accounts receivable Debtor turnover ratio is the relationship between net sales and average debtors.

\subsection{Turnover rate of inventory (FR3)}

The inventory turnover ratio is defined as ratio of cost goods sold to average inventory maintained.

\subsection{Return of stockholder equity (FR4)}

The return on equity ratio or ROE is a profitability ratio that measures the ability of a firm to generate profits from its shareholders investments in the company.

\subsection{Quick ratio (FR5)}

The quick ratio is an indicator of a company's short-term liquidity position and measures a company's ability to meet its short-term obligations with its most liquid assets.

\subsection{Operating income ratio (FR6)}

Operating income can be calculated by subtracting operating expenses, depreciation, and amortization from gross income or revenues, $=$ Net profit (Results of Operations)/Revenue from operations.

\subsection{Ratio of cash flow (FR7)}

The operating cash flow ratio is a measure of the number of times a company can pay off current debts with cash generated within the same period Cash flow ratio = Operating cash flow /current liabilities

\subsection{Return of assets (FR8)}

Return on assets is displayed as a percentage and it's calculated as: ROA = Net Income / Total Assets. 


\subsection{Market share (FR9)}

Market share is calculated by taking the company's sales over the period and dividing it by the total sales of the industry over the same period. Market share = Company's sales $/$ Total industry's sales

\section{PROBLEM STATEMENT}

There are some dimensionality reduction techniques and correlation methods used to group a range of financial ratios that characterizes business failure/success in IT companies. However these techniques have not addressed the financial efficiency. The financial efficiency of the MLP must be compared with Entropy measurement method and CRITIC method for cross validation.

\section{DATA SOURCE}

In this case, Data has been collected from 18 IT companies. Last 5 years financial data is considered for the analysis and subsequently these financial ratios are separated as 9 variables based on different parameters.

\section{LITERATURE REVIEW}

Hsiang-Hsi Liu et al. (2013) considered data envelopment analysis (DEA), three-stage DEA (3SDEA) and artificial neural network (ANN) are employed to measure the technical efficiency of 29 semi-conductor firms in Taiwan. Estimated results show that there are significant differences in efficiency scores among DEA, 3SDEA and ANN analysis. The advanced setting of the three stages mechanism of DEA does show some changes in the efficiency scores between DEA and ANN approaches.

Krzysztof Piasecki and Aleksandra Wójcicka-Wójtowicz (2017) investigated the use of different structure NN and DA in the process of the classification of banks' potential clients. The results of those different methods are juxtaposed and their performance compared.

Nor Mazlina Abu Bakar and Izah Mohd Tahir (2009) made a study to predict bank performance using multiple linear regression and neural network. The study then evaluates the performance of the two techniques with a goal to find a powerful tool in predicting the bank performance. Data of thirteen banks for the period 2001-2006 was used in the study. The study concluded that artificial neural network is the more powerful tool in predicting bank performance.

Ayan Mukhopadhyay et al. (2012) combined Data Envelopment Analysis and Multi-Layer Perceptron (MLP) to suggest a new method for prediction of bankruptcy that not only focusses on historical financial data of firms. The proposed method thus identifies firms that have a high chance of facing bankruptcy along with those that have filed for bankruptcy.

Olanrewaju A Oludolapo et al. (2012) presented techniques based on the development of multilayer perceptron (MLP) and radial basis function (RBF) of artificial neural network (ANN) models, for calculating the energy consumption of South Africa's industrial sector between 1993 and 2000. The approach examines the energy consumption in relation to the gross domestic product. The results indicate a strong agreement between model predictions and observed values,

Mehdi Alinezhad Sarokolaei et al. (2012) made a research to forecast the performance of 10 Iranian banks using multi-linear regression method and artificial neural network and to compare these two methods. To do so, the financial data related to 10 Iranian banks during the years between 2006 and 2010 were collected from the most reliable resources. 
Viju Raghupathi and Wullianallur Raghupathi (2015) deployed neural networks to examine the strategic association between hospitalization experience and treatment results. The healthcare data for the years 2009-2012 are downloaded from the Statewide Planning and Research Cooperative System (SPARCS) of the New York State Department of Health (NYSDOH).

Mahmoud H. Al-Osaimy (1998) used neural networks for predicting Islamic banks performance. A data sample of twenty six Islamic banks has been collected for the period 19911993. Seven financial ratios were constructed from the data sample. Kohonen neural network was used first to group the Islamic banks into high and low performance groups using the seven financial ratios for the performance year (1993). The results of this network have assigned twelve banks to the high performance group and fourteen banks to the low performance group.

Satish Sharma and Mikhail Shebalkov (2013) presented an application of neural network and simulation modeling to analyze and predict the performance of 883 Russian Banks over the period 2000-2010. Neural network was trained over the entire dataset, and then simulation modeling was performed generating values. Next, a combination of neural network and simulation modeling techniques was validated with the help of back-testing.

Faruk Erinci and Serhat Duranay (2016) have been estimated future-oriented performance using 2457 input and 364 output normalized data of 28 deposit bank continuously operating during 2002-2014 in Turkish Banking Sector. The study is helpful in the banking sector to the decision-making experts to help with these parameters and for the visualization of prediction results for the future.

\section{METHODOLOGY TO BE ADOPTED:}

\section{Entropy Measurement Method}

It is assumed that there is a set of $\mathrm{m}$ feasible alternatives, $\mathrm{Ai}(\mathrm{i}=1,2, \ldots, \mathrm{m})$ and $\mathrm{n}$ evaluation criteria $\mathrm{Cj}(\mathrm{j}=1,2, \ldots, n)$ in the problem.

Step-1: The decision matrix $\mathrm{X}$ which shows the performance of different alternatives with respect to various criteria is formed.

$$
X=\left[x_{i j}\right]_{m \times n}=\left[\begin{array}{cccc}
x_{11} & x_{12} & \cdots & x_{1 n} \\
x_{21} & x_{22} & \cdots & x_{2 n} \\
\vdots & \vdots & \ddots & \vdots \\
x_{m 1} & x_{m 2} & \cdots & x_{m n}
\end{array}\right](i=1,2, \ldots, m ; j=1,2, \ldots, n)
$$

$\mathrm{x}_{\mathrm{ij}}$ presents the performance value of $\mathrm{i}^{\text {th }}$ alternative on $\mathrm{j}^{\text {th }}$ criterion.

Step-2: The decision matrix is normalized. Beneficial (maximization) and non-beneficial (minimization) criteria are normalized by Eq.(2) and Eq.(3) respectively. To have the performance measures comparable and dimensionless, all the entries of the decision matrix are linear normalized using the following two equations:

$$
\begin{aligned}
& r_{i j}=\frac{x_{i j}-\min \left(x_{i j}\right)}{\max \left(x_{i j}\right)-\min \left(x_{i j}\right)} \quad i=1,2, \ldots, m \text { and } j=1,2, \ldots, n \\
& r_{i j}=\frac{\max \left(x_{i j}\right)-x_{i j}}{\max \left(x_{i j}\right)-\min \left(x_{i j}\right)} \quad i=1,2, \ldots, m \text { and } j=1,2, \ldots, n
\end{aligned}
$$

Step-3: Entropy values $\left(e_{j}\right)$ are determined for each criterion. 


$$
e_{j}=\frac{\sum_{i=1}^{m} f_{i j} \ln f_{i j}}{\ln m} \quad i=1,2, \ldots, m \text { and } j=1,2, \ldots, n
$$

where $\quad \mathrm{f}_{\mathrm{ij}}=\frac{\mathrm{r}_{\mathrm{ij}}}{\sum_{\mathrm{i}=1}^{\mathrm{m}} \mathrm{r}_{\mathrm{ij}}}$ and $0<\mathrm{e}_{\mathrm{j}}<1$.

If $f_{i j}$ are all the same, then the entropy values of each criterion is the maximum $\left(e_{j}=1\right)$. If $f_{i j}$ is 0 , then $\mathrm{f}_{\mathrm{ij}} \ln \mathrm{f}_{\mathrm{ij}}$ is 0 (Wu et al., 2011).

Step-4: Entropy weights $\left(\mathrm{W}_{\mathrm{j}}\right)$ are calculated.

$$
\mathrm{W}_{\mathrm{j}}=\frac{1-\mathrm{e}_{\mathrm{j}}}{\mathrm{n}-\sum_{\mathrm{i}=1}^{\mathrm{m}} \mathrm{e}_{\mathrm{j}}} \text { where } \sum_{\mathrm{j}=1}^{\mathrm{n}} \mathrm{W}_{\mathrm{j}}=1
$$

$\left(1-e_{j}\right)$ represents the inherent contrast intensity of each criterion. In other words it is the degree of divergence of the intrinsic information of each criterion. If $\left(1-e_{j}\right)$ is normalized, then the final weights of each criterion can be obtained. The entropy weight is a parameter that describes the importance of the criterion. The smaller the value of the entropy, the larger the entropy-based weight, then the specific criterion provides more information and this criterion becomes more important than the other criteria in the decision making process (Wu et al., 2011).

\section{CRITIC METHOD}

It is based on analytical testing of the decision matrix in order to determine the information contained in the criteria by which variants are evaluated. For each criteria $\mathrm{x}_{\mathrm{ij}}$ membership function $r_{i j}$ which translates all the values of criteria $f_{j}$ into interval $[0,1]$, is defined

$$
r_{i j}=\frac{x_{i j}-x_{j}^{\min }}{x_{j}^{\max }-x_{j}^{\min }}
$$

This transformation is based on the concept of an ideal point. In this way, the initial matrix is converted into a matrix with generic elements $r_{i j}$.

Each vector $r_{j}$ is characterised by the standard deviation $\left(s_{j}\right)$, which quantifies the contrast intensity of the corresponding criterion. So, the standard deviation of $r_{j}$ is a measure of the value of that criterion to be considered in the decision-making process. Next, a symmetric matrix is constructed, with dimensions $\mathrm{m} \times \mathrm{m}$ and a generic element ljk, which is the linear correlation coefficient between the vectors $r_{j}$ and $r_{k}$. It can be seen that the more discordant the scores of the alternatives in criteria $\mathrm{j}$ and $\mathrm{k}$ are, the lower is the value $l_{\mathrm{jk} .}$. In this sense, Eq. (6) represents a measure of the conflict created by criterion $\mathrm{j}$ with respect to the decision situation defined by the rest of the criteria:

$$
\sum_{\mathrm{k}=1}^{\mathrm{m}}\left(1-l_{\mathrm{jk}}\right)
$$

The amount of information $\mathrm{C}_{\mathrm{j}}$ conveyed by the $\mathrm{j}^{\text {th }}$ criterion can be determined by composing the measures which quantify the above 2 notions through the multiplicative aggregation formula (Eq. (7)).

$$
\mathrm{C}_{\mathrm{j}}=\sigma_{\mathrm{j}} \sum_{\mathrm{k}=1}^{\mathrm{m}}\left(1-l_{\mathrm{kj}}\right)
$$


The higher the value $\mathrm{C}_{\mathrm{j}}$ is, the larger is the amount of information transmitted by the corresponding criterion and the higher is its relative importance for the decision-making process. Objective weights are derived by normalizing these values to unity (Eq. (18)).

$$
\mathrm{w}_{\mathrm{j}}=\mathrm{C}_{\mathrm{j}}\left[\sum_{\mathrm{k}=1}^{\mathrm{m}} \mathrm{C}_{\mathrm{k}}\right]^{-1}
$$

Objective criteria weights are obtained by normalizing the values $C_{j}$ :

$$
w_{j}=\frac{c_{j}}{\sum_{i=1}^{m} c_{i}}
$$

\section{RESULTS AND ANALYSIS}

Nine financial ratios of 18 software companies during five financial years as discussed. Relative weights of the financial ratios are determined through objective methods namely MLP of artificial neural network, entropy method and critic method. Finally average weights of the financial ratios are determined.

In this study, FR1, FR2 and FR3 are considered as input financial ratios and FR4, FR5, FR6, FR7, FR8 and FR9 are considered as output ratios.

CCR model of data envelopment analysis is used for determining the category of financial efficiency based on input and output financial ratios using LINGO 8.0 software.

Table 1 Financial efficiency of software companies during $1^{\text {st }}$ financial year

\begin{tabular}{|c|c|c|c|c|c|c|c|c|c|c|c|}
\hline $\begin{array}{c}\text { Software } \\
\text { Companies } \\
\text { (SWC) }\end{array}$ & FR1 & FR2 & FR3 & FR4 & FR5 & FR6 & FR7 & FR8 & FR9 & $\begin{array}{c}\text { Financial } \\
\text { Efficiency }\end{array}$ & $\begin{array}{c}\text { Financial } \\
\text { Efficiency } \\
\text { Group }\end{array}$ \\
\hline SWC1 & 0.1298 & 6.1418 & 981.2177 & -0.6244 & 0.3774 & 0.0697 & 0.0404 & -0.0811 & 0.0052 & 0.0622 & NE \\
\hline SWC2 & 0.0047 & 6.3151 & 136.2825 & 46.4965 & 2.1518 & 0.2500 & 0.6807 & 0.2166 & 0.1274 & 1 & $\mathrm{E}$ \\
\hline SWC3 & 0.0050 & 6.4964 & 3016.0000 & 37.2587 & 3.8368 & 0.2671 & 0.7710 & 0.1861 & 0.1988 & 0.6308 & $\mathrm{NE}$ \\
\hline SWC4 & 0.0172 & 4.7198 & 1350.6822 & 6.7102 & 1.5198 & 0.1402 & 0.2634 & 0.1153 & 0.0107 & 0.474 & $\mathrm{NE}$ \\
\hline SWC5 & 0.0147 & 6.9437 & 1299.9365 & 4.6751 & 2.5468 & 0.0976 & 0.4650 & 0.0687 & 0.0037 & 0.3568 & $\mathrm{NE}$ \\
\hline SWC6 & 0.0199 & 5.7679 & 1301.4115 & 10.8106 & 3.8261 & 0.2012 & 0.7064 & 0.2147 & 0.0120 & 0.736 & $\mathrm{NE}$ \\
\hline SWC7 & 0.0300 & 3.6304 & 1299.8089 & 1.4404 & 2.4361 & 0.1694 & 0.1465 & 0.0432 & 0.0103 & 1 & $\mathrm{E}$ \\
\hline SWCS & 0.0331 & 4.5276 & 417.7281 & 3.7979 & 2.7036 & 0.1537 & 0.2895 & 0.1256 & 0.0091 & 0.7176 & $\mathrm{NE}$ \\
\hline SWC9 & 0.0043 & 5.3117 & 1307.6618 & 32.3109 & 9.2470 & 0.3740 & 0.7097 & 0.1398 & 0.0148 & 1 & $\mathrm{E}$ \\
\hline SWC10 & 0.0257 & 6.0927 & 1300.9625 & 6.2320 & 3.4367 & 0.2482 & 0.8481 & 0.1601 & 0.0066 & 0.781 & $\mathrm{NE}$ \\
\hline SWC11 & 0.0221 & 3.3705 & 1297.3562 & 1.7584 & 0.3089 & 0.3276 & 0.2878 & 0.0389 & 0.0099 & 1 & $\mathrm{E}$ \\
\hline SWC12 & 0.0427 & 5.0058 & 146.0758 & 2.4187 & 3.9531 & 0.1166 & 0.6923 & 0.1034 & 0.0018 & 1 & $\mathrm{E}$ \\
\hline SWC13 & 0.0160 & 8.9554 & 1466.2900 & 7.3926 & 2.2570 & 0.0636 & 0.4550 & 0.1180 & 0.0062 & 0.2488 & $\mathrm{NE}$ \\
\hline SWC14 & 0.0029 & 5.0615 & 3116.4230 & 97.8397 & 3.2098 & 0.3075 & 0.8360 & 0.2854 & 0.3244 & 1 & $\mathrm{E}$ \\
\hline SWC15 & 0.0792 & 5.3193 & 4098.0000 & 2.4120 & 1.8727 & 0.1773 & 0.7977 & 0.1911 & 0.0031 & 0.5258 & $\mathrm{NE}$ \\
\hline SWC16 & 0.0146 & 6.2134 & 1405.6346 & 12.9713 & 1.9744 & 0.2225 & 0.2496 & 0.1900 & 0.0746 & 0.4126 & $\mathrm{NE}$ \\
\hline SWC17 & 0.0099 & 5.3555 & 121.6289 & 16.1199 & 2.2232 & 0.2219 & 0.5476 & 0.1599 & 0.1722 & 1 & $\mathrm{E}$ \\
\hline SWC18 & 0.0295 & 6.7336 & 16.9201 & 5.4265 & 1.9696 & 0.1534 & 0.5656 & 0.1598 & 0.0093 & 1 & $\mathrm{E}$ \\
\hline
\end{tabular}

Note: E- Efficient; NE- Not Efficient:

From Table-1 it is observed that software companies namely: SWC2, SWC7, SWC9, SWC11, SWC12, SWC14, SWC17 and SWC 18 are grouped as efficient decision making units (Software companies). Remaining companies are arrived as Not-efficient organizations, during $1^{\text {st }}$ Financial Year. 
Table 2 Financial efficiency of software companies during $2^{\text {nd }}$ financial year

\begin{tabular}{|c|c|c|c|c|c|c|c|c|c|c|c|}
\hline $\begin{array}{c}\text { Software } \\
\text { Companies } \\
\text { (SWC) }\end{array}$ & FR1 & FR2 & FR3 & FR4 & FR5 & FR6 & FR7 & FR8 & FR9 & Financial \\
Efficiency & $\begin{array}{c}\text { Financial } \\
\text { Efficiency }\end{array}$ \\
\hline SWC1 & 0.1660 & 6.9077 & 836.6929 & -1.6170 & 0.4026 & 0.1284 & -0.0290 & -0.2684 & 0.004693 & 0.1845 & NE \\
\hline SWC2 & 0.0080 & 6.0060 & 201.6980 & 26.0209 & 2.4413 & 0.2309 & 0.5317 & 0.2073 & 0.128143 & 0.7296 & NE \\
\hline SWC3 & 0.0086 & 5.9033 & 1301.0146 & 21.6294 & 3.4819 & 0.2791 & 0.5263 & 0.1857 & 0.186165 & 0.0622 & NE \\
\hline SWC4 & 0.0165 & 4.3579 & 202.6233 & 6.3012 & 1.5730 & 0.1085 & 0.5998 & 0.1038 & 0.010439 & 1 & $\mathrm{E}$ \\
\hline SWC5 & 0.0136 & 8.0919 & 1299.7027 & 1.5732 & 2.3440 & 0.0468 & 0.2834 & 0.0213 & 0.003535 & 0.2299 & NE \\
\hline SWC6 & 0.0315 & 5.4938 & 1300.7675 & 6.4074 & 3.2675 & 0.1991 & 0.9353 & 0.2020 & 0.012436 & 0.6369 & NE \\
\hline SWC7 & 0.0282 & 8.2604 & 1299.9875 & 3.2103 & 2.5911 & 0.1496 & 0.4397 & 0.0905 & 0.020233 & 0.2515 & NE \\
\hline SWC8 & 0.0303 & 4.0544 & 297.3188 & 1.8688 & 2.2119 & 0.1391 & 0.3963 & 0.0566 & 0.008284 & 1 & $\mathrm{E}$ \\
\hline SWC9 & 0.0067 & 6.0902 & 1299.1862 & 28.1806 & 1.8961 & 0.3974 & 0.3751 & 0.1901 & 0.013634 & 0.5616 & $\mathrm{NE}$ \\
\hline SWC10 & 0.0444 & 5.7189 & 1301.0629 & 3.6329 & 3.5237 & 0.2064 & 0.7971 & 0.1614 & 0.006603 & 0.5479 & $\mathrm{NE}$ \\
\hline SWC11 & 0.0191 & 3.4431 & 1297.4939 & 1.5197 & 0.4284 & 0.3517 & 0.2067 & 0.0290 & 0.012847 & 1 & $\mathrm{E}$ \\
\hline SWC12 & 0.0382 & 5.2617 & 385.7953 & 5.6026 & 4.6112 & -0.1447 & 1.7252 & 0.2139 & 0.001494 & 1 & $\mathrm{E}$ \\
\hline SWC13 & 0.0130 & 6.4877 & 354.6815 & 12.7091 & 2.0666 & 0.0997 & 0.2163 & 0.1654 & 0.005873 & 0.4523 & $\mathrm{NE}$ \\
\hline SWC14 & 0.0027 & 4.8954 & 4486.3619 & 101.3539 & 2.6936 & 0.2587 & 0.8544 & 0.2695 & 0.330468 & 1 & $\mathrm{E}$ \\
\hline SWC15 & 0.0662 & 5.4860 & 4635.4483 & 3.3044 & 1.9887 & 0.2087 & 0.7669 & 0.2188 & 0.002966 & 0.3408 & $\mathrm{NE}$ \\
\hline SWC16 & 0.0242 & 4.7352 & 1074.5364 & 5.4698 & 2.0811 & 0.1854 & 0.3548 & 0.1324 & 0.078983 & 0.7068 & $\mathrm{NE}$ \\
\hline SWC17 & 0.0083 & 5.3047 & 102.6374 & 17.5428 & 2.1787 & 0.2194 & 0.5451 & 0.1459 & 0.163931 & 1 & $\mathrm{E}$ \\
\hline SWC18 & 0.0253 & 6.5412 & 18.0122 & 5.9686 & 2.0244 & 0.1475 & 0.7641 & 0.1510 & 0.009273 & 1 & $\mathrm{E}$ \\
\hline
\end{tabular}

Note: E- Efficient; NE- Not Efficient:

From Table-2 it is observed that software companies namely: SWC4, SWC8, SWC11, SWC12, SWC14, SWC14, SWC17 and SWC 18 are grouped as efficient decision making units (Software companies). Remaining companies are arrived as in Not-efficient organizations, during $2^{\text {nd }}$ Financial Year.

Table 3 Financial efficiency of software companies during $3^{\text {rd }}$ financial year

\begin{tabular}{|c|c|c|c|c|c|c|c|c|c|c|c|}
\hline $\begin{array}{c}\text { Software } \\
\begin{array}{c}\text { Companies } \\
\text { (SWC) }\end{array}\end{array}$ & FR1 & FR2 & FR3 & FR4 & FR5 & FR6 & FR7 & FR8 & FR9 & Financial \\
Efficiency & $\begin{array}{c}\text { Financial } \\
\text { Efficiency }\end{array}$ \\
\hline SWC1 & 0.4034 & 6.2637 & 1689.2743 & -0.8610 & 0.5238 & -0.6959 & 0.3602 & -0.3473 & 0.003574 & 0.0551 & NE \\
\hline SWC2 & 0.0072 & 4.3669 & 116.0055 & 19.8611 & 2.4697 & 0.2137 & 0.3496 & 0.1421 & 0.098853 & 1 & $\mathrm{E}$ \\
\hline SWC3 & 0.0152 & 5.9346 & 1302.2510 & 11.7911 & 4.5542 & 0.2735 & 0.7370 & 0.1790 & 0.198242 & 0.994 & $\mathrm{NE}$ \\
\hline SWC4 & 0.0171 & 4.6595 & 91.6409 & 7.4767 & 1.9310 & 0.1348 & 0.7307 & 0.1279 & 0.010237 & 1 & $\mathrm{E}$ \\
\hline SWC5 & 0.0269 & 4.5697 & 1300.8451 & 1.1948 & 3.3349 & 0.0287 & 0.2913 & 0.0321 & 0.001673 & 0.8169 & $\mathrm{NE}$ \\
\hline SWC6 & 0.0506 & 5.5994 & 1299.7556 & 3.2926 & 2.3899 & 0.1757 & 0.4914 & 0.1666 & 0.014836 & 0.4921 & $\mathrm{NE}$ \\
\hline SWC7 & 0.0295 & 9.5450 & 2545.3073 & 3.0045 & 4.3873 & 0.1419 & 0.9124 & 0.0885 & 0.019306 & 0.3932 & $\mathrm{NE}$ \\
\hline SWC8 & 0.0263 & 4.4945 & 503.1328 & 4.4118 & 1.8866 & 0.1755 & 0.4832 & 0.1160 & 0.008534 & 0.7442 & $\mathrm{NE}$ \\
\hline SWC9 & 0.0074 & 5.7670 & 1302.2844 & 24.7672 & 4.5831 & 0.3916 & 0.6701 & 0.1828 & 0.013116 & 1 & $\mathrm{E}$ \\
\hline SWC10 & 0.0373 & 5.8828 & 1301.0457 & 3.4663 & 3.5089 & 0.1693 & 0.5257 & 0.1293 & 0.007341 & 0.621 & $\mathrm{NE}$ \\
\hline SWC11 & 0.0172 & 2.3494 & 1297.4821 & 1.1296 & 0.4181 & 0.3021 & 0.2125 & 0.0194 & 0.012063 & 1 & $\mathrm{E}$ \\
\hline SWC12 & 0.0278 & 5.8140 & 323.5205 & 11.6416 & 4.3087 & 0.0224 & 1.8110 & 0.3235 & 0.001534 & 1 & $\mathrm{E}$ \\
\hline SWC13 & 0.0106 & 5.8396 & 201.6851 & 15.0751 & 1.6740 & 0.0989 & 0.4587 & 0.1599 & 0.006161 & 0.6341 & $\mathrm{NE}$ \\
\hline SWC14 & 0.0022 & 4.8818 & 4862.4259 & 123.1980 & 4.2836 & 0.2824 & 1.0727 & 0.2723 & 0.344937 & 1 & $\mathrm{E}$ \\
\hline SWC15 & 0.0514 & 5.8231 & 5706.8276 & 4.9714 & 2.2688 & 0.2304 & 0.5511 & 0.2557 & 0.003414 & 0.3571 & $\mathrm{NE}$ \\
\hline SWC16 & 0.0193 & 4.8275 & 685.9136 & 6.8723 & 2.2918 & 0.1612 & 0.4568 & 0.1327 & 0.084116 & 0.6922 & $\mathrm{NE}$ \\
\hline SWC17 & 0.0066 & 5.3613 & 79.0081 & 18.0285 & 2.0085 & 0.2107 & 0.4899 & 0.1191 & 0.162693 & 1 & $\mathrm{E}$ \\
\hline SWC18 & 0.0233 & 5.9399 & 20.2269 & 6.4878 & 2.3456 & 0.1486 & 0.5056 & 0.1509 & 0.009372 & 1 & $\mathrm{E}$ \\
\hline
\end{tabular}

Note: E- Efficient; NE- Not Efficient:

From Table-3 it is observed that software companies namely: SWC2, SWC4, SWC9, SWC11, SWC12, SWC14, SWC17 and SWC 18 are grouped as efficient decision making units (Software companies). Remaining companies are arrived as in not efficient organizations, during $3^{\text {rd }}$ Financial Year. 
Some Objective Methods for Determining Relative Importance of Financial Ratios

Table 4 Financial efficiency of software companies during $4^{\text {th }}$ financial year

\begin{tabular}{|l|c|c|c|c|c|c|c|c|c|c|c|}
\hline $\begin{array}{c}\text { Software } \\
\begin{array}{c}\text { Companies } \\
\text { (SWC) }\end{array}\end{array}$ & FR1 & FR2 & FR3 & FR4 & FR5 & FR6 & FR7 & FR8 & FR9 & Financial & Financial \\
Efficiency & Efficiency \\
\hline SWC1 & 0.7223 & 5.2397 & 973.2874 & 0.0800 & 0.4050 & 0.1564 & 0.1149 & 0.0578 & 0.002826 & 0.1624 & NE \\
\hline SWC2 & 0.0062 & 5.9378 & 137.5962 & 30.1965 & 2.3498 & 0.2183 & 0.7172 & 0.1868 & 0.133911 & 1 & $\mathrm{E}$ \\
\hline SWC3 & 0.0136 & 5.7910 & 1302.3524 & 12.5463 & 4.6421 & 0.2717 & 0.7663 & 0.1708 & 0.192792 & 0.9407 & NE \\
\hline SWC4 & 0.0148 & 4.5157 & 73.0530 & 6.3366 & 1.9498 & 0.1050 & 0.2847 & 0.0938 & 0.009346 & 0.7949 & NE \\
\hline SWC5 & 0.0160 & 6.1482 & 1299.4242 & 2.7725 & 2.1025 & 0.0812 & 0.2177 & 0.0443 & 0.001577 & 0.2904 & NE \\
\hline SWC6 & 0.0491 & 5.6034 & 1300.2779 & 2.4917 & 2.8430 & 0.1345 & 0.8781 & 0.1224 & 0.014741 & 0.5793 & NE \\
\hline SWC7 & 0.0285 & 9.5181 & 2494.1024 & 3.7619 & 4.4497 & 0.1586 & 0.6872 & 0.1073 & 0.017106 & 0.388 & NE \\
\hline SWC8 & 0.0247 & 5.2965 & 7740.3333 & 4.0733 & 2.0441 & 0.1713 & 0.6070 & 0.1004 & 0.007888 & 0.3356 & NE \\
\hline SWC9 & 0.0070 & 5.7150 & 1299.1445 & 27.9112 & 1.8600 & 0.3908 & 0.4030 & 0.1961 & 0.012461 & 0.8823 & NE \\
\hline SWC10 & 0.0338 & 6.3758 & 1301.5167 & 3.7684 & 3.9173 & 0.1583 & 0.6165 & 0.1274 & 0.008103 & 0.5113 & NE \\
\hline SWC11 & 0.0156 & 1.9229 & 1297.6098 & 1.0150 & 0.5288 & 0.3044 & -0.0278 & 0.0158 & 0.008952 & 1 & $\mathrm{E}$ \\
\hline SWC12 & 0.0256 & 5.3704 & 337.9028 & 4.9497 & 5.8861 & 0.1069 & 0.2594 & 0.1266 & 0.001315 & 1 & $\mathrm{E}$ \\
\hline SWC13 & 0.0087 & 5.4230 & 435.4106 & 15.0723 & 1.7774 & 0.0808 & 0.3342 & 0.1305 & 0.006674 & 0.5501 & $\mathrm{NE}$ \\
\hline SWC14 & 0.0019 & 5.0532 & 4630.0000 & 133.4467 & 5.1366 & 0.2739 & 1.4336 & 0.2539 & 0.332091 & 1 & $\mathrm{E}$ \\
\hline SWC15 & 0.0432 & 5.3794 & 1301.3368 & 5.6127 & 3.7613 & 0.2211 & 0.8859 & 0.2426 & 0.003483 & 0.8037 & $\mathrm{NE}$ \\
\hline SWC16 & 0.0168 & 5.2467 & 492.2367 & 6.4104 & 2.0357 & 0.1436 & 0.4926 & 0.1079 & 0.082035 & 0.6019 & $\mathrm{NE}$ \\
\hline SWC17 & 0.0059 & 5.7028 & 94.8469 & 17.4719 & 2.0497 & 0.2042 & 0.5785 & 0.1036 & 0.156095 & 1 & $\mathrm{E}$ \\
\hline SWC18 & 0.0209 & 5.6944 & 22.4173 & 5.2345 & 2.5092 & 0.1250 & 0.5587 & 0.1092 & 0.008602 & 1 & $\mathrm{E}$ \\
\hline
\end{tabular}

Note: E- Efficient; NE- Not Efficient:

From Table-4 it is observed that software companies namely: SWC2, SWC11, SWC12, SWC14, SWC17 and SWC 18 are grouped as efficient decision making units (Software companies). Remaining companies are arrived as not efficient organizations, during $4^{\text {th }}$ Financial Year

Table 5 Financial efficiency of software companies during $5^{\text {th }}$ financial year

\begin{tabular}{|c|c|c|c|c|c|c|c|c|c|c|c|}
\hline $\begin{array}{c}\text { Software } \\
\begin{array}{c}\text { Companies } \\
\text { (SWC) }\end{array}\end{array}$ & FR1 & FR2 & FR3 & FR4 & FR5 & FR6 & FR7 & FR8 & FR9 & Financial \\
Efficiency & $\begin{array}{c}\text { Financial } \\
\text { Efficiency }\end{array}$ \\
\hline SWC1 & 0.9961 & 4.7757 & 874.7225 & 0.0436 & 0.5345 & 0.1572 & 0.1356 & 0.0434 & 0.002695 & 0.1607 & NE \\
\hline SWC2 & 0.0058 & 5.6376 & 175.5491 & 31.3705 & 2.4869 & 0.2224 & 0.7369 & 0.1808 & 0.13749 & 1 & $\mathrm{E}$ \\
\hline SWC3 & 0.0135 & 5.5390 & 1302.0376 & 14.7325 & 4.3691 & 0.2696 & 0.8507 & 0.1992 & 0.19174 & 1 & $\mathrm{E}$ \\
\hline SWC4 & 0.0138 & 4.6083 & 97.9456 & 6.6715 & 2.0681 & 0.1013 & 0.6633 & 0.0923 & 0.009961 & 1 & $\mathrm{E}$ \\
\hline SWC5 & 0.0141 & 7.4214 & 1299.6222 & 5.9038 & 2.2742 & 0.1220 & 0.2904 & 0.0833 & 0.002222 & 0.3276 & $\mathrm{NE}$ \\
\hline SWC6 & 0.0433 & 5.7151 & 1300.1192 & 3.4783 & 2.7053 & 0.1356 & 0.7575 & 0.1505 & 0.014853 & 0.5989 & $\mathrm{NE}$ \\
\hline SWC7 & 0.0276 & 9.0946 & 1300.8642 & 4.3333 & 3.3514 & 0.1622 & 0.6429 & 0.1194 & 0.017797 & 0.4101 & $\mathrm{NE}$ \\
\hline SWC8 & 0.0228 & 5.6774 & 8298.0000 & 4.5561 & 1.9668 & 0.1678 & 0.4235 & 0.1038 & 0.008133 & 02613 & $\mathrm{NE}$ \\
\hline SWC9 & 0.0071 & 5.2477 & 1301.6730 & 28.9909 & 4.0529 & 0.4000 & 0.9130 & 0.2070 & 0.01231 & 1 & $\mathrm{E}$ \\
\hline SWC10 & 0.0300 & 6.3194 & 1301.5781 & 4.0386 & 3.9706 & 0.1545 & 0.7778 & 0.1210 & 0.008248 & 0.6438 & $\mathrm{NE}$ \\
\hline SWC11 & 0.0145 & 2.0309 & 1297.6936 & -0.6395 & 0.6016 & 0.2889 & 0.0303 & -0.0092 & 0.007778 & 1 & $\mathrm{E}$ \\
\hline SWC12 & 0.0232 & 6.4312 & 1303.9958 & 4.8171 & 6.0674 & 0.1381 & 0.6861 & 0.1120 & 0.001368 & 0.8937 & $\mathrm{NE}$ \\
\hline SWC13 & 0.0084 & 5.3559 & 1299.2248 & 18.5482 & 1.9296 & 0.0941 & 0.5448 & 0.1561 & 0.006672 & 0.7028 & $\mathrm{NE}$ \\
\hline SWC14 & 0.0018 & 5.1768 & 3854.8085 & 135.2147 & 4.4735 & 0.2641 & 1.2029 & 0.2430 & 0.334704 & 1 & $\mathrm{E}$ \\
\hline SWC15 & 0.0655 & 5.0276 & 1301.6462 & 3.8542 & 4.0296 & 0.2513 & 0.9269 & 0.2524 & 0.003769 & 0.9091 & $\mathrm{NE}$ \\
\hline SWC16 & 0.0145 & 5.2001 & 410.4457 & 8.6027 & 1.9674 & 0.1530 & 0.3862 & 0.1248 & 0.083667 & 0.6062 & $\mathrm{NE}$ \\
\hline SWC17 & 0.0116 & 5.5646 & 121.0707 & 8.8448 & 1.9927 & 0.1906 & 0.5226 & 0.1027 & 0.148143 & 0.9341 & $\mathrm{NE}$ \\
\hline SWC18 & 0.0193 & 5.2878 & 25.0863 & 5.3685 & 2.6411 & 0.1174 & 0.3182 & 0.1039 & 0.00845 & 1 & $\mathrm{E}$ \\
\hline
\end{tabular}
Note: E- Efficient; NE- Not Efficient:

From Table-5 it is observed that software companies namely: SWC2, SWC3, SWC4, SWC9, SWC11, SWC14 and SWC 18 are grouped as efficient decision making units (Software companies). Remaining companies are arrived as not efficient organizations, during $5^{\text {th }}$ Financial Year. 

MLP.

The efficiency groups obtained through DEA are considered as dependent variables in

\section{MLP METHOD}

The aim of this study was to examine relative importance of financial ratios through MLP neural networks by analyzing data obtained from the annual reports from $1^{\text {st }} \mathrm{FY}$ to $5^{\text {th }} \mathrm{FY}$ of the 18 software companies. MLP of Neural networks is implemented to the case study using SPSS 17 and the following outputs of the analysis are discussed in the following sections.

\subsection{MLP Network information}

- $\quad$ Number of inputs $=9$ Financial Ratios.

- Number of output units $=1$ (financial Efficiency Group)

- $\quad$ Number of hidden units $=13$

- $\quad$ Training dataset $=90 \%$ of the sample

- Testing dataset $=5 \%$ of the sample.

- Holdout dataset $=5 \%$ of the sample.

- Type of training = Batch training

- Optimizing Algorithm = scaled congregated method

- $\quad$ Training options, Initial $\lambda=0.0000005$

\subsection{Case Processing Summary}

Table- 6 gives information about the datasets used to build the ANN model. From the table it is observed that the training, testing and holdout dataset contains $90 \%, 5 \%$ and $5 \%$ of the sample respectively.

Table 6 Case processing summary

\begin{tabular}{|l|l|c|c|}
\hline \multicolumn{2}{|c|}{} & N & Percent \\
\hline \multirow{3}{*}{ Sample } & Training & 90 & 90 \\
\cline { 2 - 4 } & Testing & 5 & 5 \\
\cline { 2 - 4 } & Holdout & 5 & 5 \\
\hline Valid & 100 & 100 \\
\hline Excluded & 0 & \\
\hline Total & 100 & \\
\hline
\end{tabular}

Network Information: The Table-7 shows network information. The table shows the number of neurons in every layer. Input layer contains 9 factors (FR1, FR2,..,FR9). The Automatic architecture selection chose 13 nodes for the hidden layer, while the output layer had 2 nodes and the depended variable financial efficiency group. For the hidden layer the activation function was the hyperbolic tangent, while for the output layer also the softmax function is used.

Table 7 Network information

\begin{tabular}{|l|c|c|c|}
\hline Input Layer & Factors & 1 & FR1 \\
\cline { 3 - 4 } & & 2 & FR2 \\
\cline { 3 - 4 } & & 3 & FR3 \\
\cline { 3 - 4 } & & 4 & FR4 \\
\cline { 3 - 4 } & & 5 & FR5 \\
\cline { 3 - 4 } & & 6 & FR6 \\
\cline { 3 - 4 } & & 7 & FR7 \\
\hline
\end{tabular}




\begin{tabular}{|l|l|c|c|}
\hline \multirow{4}{*}{} & & 8 & \multicolumn{1}{|c|}{ FR8 } \\
\cline { 2 - 4 } & & 9 & FR9 \\
\cline { 2 - 3 } & Number of Units & 723 \\
\hline Hidden Layer(s) & Number of Hidden Layers & 1 \\
\cline { 2 - 3 } & Number of Units in Hidden Layer 1 & \\
\cline { 2 - 3 } & Activation Function & 13 \\
\hline \multirow{3}{*}{ Output Layer } & Dependent Variables & 1 & Hyperbolic tangent \\
\cline { 2 - 3 } & Number of Units & 2 \\
\cline { 2 - 3 } & Activation Function & Softmax \\
\cline { 2 - 3 } & Error Function & Cross-entropy \\
\hline
\end{tabular}

Model Summary: The model summary is shown in Table-8.

Table 8 Model Summary

\begin{tabular}{|l|l|l|}
\hline \multirow{3}{*}{ Training } & Cross entropy error & $6.524 \mathrm{E}-5$ \\
\cline { 2 - 3 } & Percent incorrect predictions & $0.0 \%$ \\
\cline { 2 - 3 } & Stopping rule used & $\begin{array}{l}\text { Training error ratio criterion }(0.001) \\
\text { achieved }\end{array}$ \\
\cline { 2 - 3 } & Training time & $0: 00: 00.28$ \\
\hline \multirow{2}{*}{ Testing } & Cross entropy error & $1.255 \mathrm{E}-6$ \\
\cline { 2 - 3 } & Percent incorrect predictions & $0.0 \%$ \\
\hline Holdout & Percent incorrect predictions & $0.0 \%$ \\
\hline Dependent variable: GROUP \\
\hline
\end{tabular}

Table- 8 provides information related to the results of training, testing and holdout samples. Cross entropy error is given for training, testing and holdout samples. The small value $(6.524$ E-5) of this error of training set indicates the power of the model to predict financial efficiency. The cross entropy error (1.255 E-6) is also very less for the testing data set, meaning that the network model has not been over-fitted to the training data. The result justifies the role of testing sample which is to prevent overtraining. From the results, it is observed that, there are no incorrect predictions based on training and testing samples.

Classification Summary: Table-9 displays classification for categorical dependent variable (financial efficiency).

Table 9 Classification

\begin{tabular}{|l|l|c|c|c|}
\hline \multirow{2}{*}{ Sample } & \multicolumn{1}{|c|}{ Observed } & \multicolumn{3}{|c|}{ Predicted } \\
\cline { 3 - 5 } & & $\mathrm{E}$ & $\mathrm{NE}$ & Percent correct \\
\hline \multirow{3}{*}{ Training } & $\mathrm{E}$ & 36 & 0 & 100.0 \\
\cline { 2 - 5 } & NE & 0 & 54 & 100.0 \\
\cline { 2 - 5 } & Overall percent & 40.0 & $60.0 \%$ & 100.0 \\
\hline \multirow{3}{*}{ Testing } & $\mathrm{E}$ & 3 & 0 & 100.0 \\
\cline { 2 - 5 } & NE & 0 & 2 & 100.0 \\
\cline { 2 - 5 } & Overall percent & 60.0 & $40.0 \%$ & 100.0 \\
\hline \multirow{3}{*}{ Holdout } & $\mathrm{E}$ & 2 & 0 & 100.0 \\
\cline { 2 - 5 } & NE & 0 & 3 & 100.0 \\
\cline { 2 - 5 } & Overall percent & 40.0 & $60.0 \%$ & 100.0 \\
\hline Dependent Variable: GROUP & \multicolumn{3}{|l}{} \\
\hline
\end{tabular}

As can be seen, the MLP network correctly classified all 18 software companies out of 90 observations, in the training sample in training and sample and two out of two in testing sample 
were correctly classified. Overall $100.0 \%$ of the training cases and testing case were correctly classified.

Importance Analysis: Table-10 gives the impact of each independent variable in the ANN model in terms of relative and normalized importance.

Table-10 Independent variable importance

\begin{tabular}{|l|l|l|}
\hline & Importance & $\begin{array}{l}\text { Normalized } \\
\text { importance }\end{array}$ \\
\hline FR1 & 0.118 & $83.5 \%$ \\
\hline FR2 & 0.108 & $76.0 \%$ \\
\hline FR3 & 0.132 & $93.4 \%$ \\
\hline FR4 & 0.109 & $76.9 \%$ \\
\hline FR5 & 0.104 & $73.4 \%$ \\
\hline FR6 & 0.095 & $66.8 \%$ \\
\hline FR7 & 0.100 & $70.6 \%$ \\
\hline FR8 & 0.092 & $64.8 \%$ \\
\hline FR9 & 0.142 & $100.0 \%$ \\
\hline
\end{tabular}

From the Table-10, it is apparent that the financial ratio FR9 has the greatest effect on financial efficiency since the relative importance of the variable is 0.142 . FR8 has the lowest effect on the financial efficiency since the relative importance of the variable is 0.0928 . The importance of the variables, i.e., how sensitive is the model is in the change of each input variable is depicted.

The accuracy of prediction of overall financial performance measured by MLP is measured by the area under the ROC curve. An area of 1 represents a perfect test; an area of 0.5 represents a worthless test. A rough guide for classifying the accuracy of prediction is Excellent ( 0.9 to $1.0)$, Good (0.8 to 0.9), Fair (0.7 to 0.8), Poor (0.6 to 0.7) and Fail (0.5 to 0.6). Excellent prediction of overall financial performance is obtained through the proposed MLP is obtained in this study, since the area under ROC for all groups is equal to 1.00 .

\section{ENTROPY MEASUREMENT METHOD}

Decision matrix: The decision matrix shows the payoff eighteen software companies during 5 financial years with respect to nine financial ratios. The decision matrix is shown in Tables A.1A.5 of Appendix.

Normalized Decision matrix: The normalized decision matrix is shown in Tables A.6-A.10 of Appendix.

Entropy values: Entropy values are shown in Table-11.

Table 11 Entropy values

\begin{tabular}{|c|c|c|c|c|c|c|c|c|c|}
\hline FRs & FR1 & FR2 & FR3 & FR4 & FR5 & FR6 & FR7 & FR8 & FR9 \\
\hline$e_{j}$ & 0.4374 & 0.6638 & 0.5482 & 0.4907 & 0.6517 & 0.6427 & 0.6147 & 0.6649 & 0.4801 \\
\hline
\end{tabular}

Inherent contrast intensity $\left(1-e_{j}\right)$ : Inherent contrast intensity is the degree of divergence of the intrinsic information of each criterion is determined Entropy Weight $\left(w_{j}\right)$ : Entropy weight is determined The entropy weights are shown in Table-12. Entropy weight is a parameter that describes the importance of the criterion. Smaller the value of the entropy, the larger the entropy based weight.

Table 12 Entropy weight

\begin{tabular}{|l|l|l|l|l|l|l|l|l|l|}
\hline FRs & FR1 & FR2 & FR3 & FR4 & FR5 & FR6 & FR7 & FR8 & FR9 \\
\hline
\end{tabular}




\begin{tabular}{|c|c|c|c|c|c|c|c|c|c|}
$\mathrm{w}_{\mathrm{j}}$ & 0.2345 & 0.0304 & 0.1225 & 0.1749 & 0.0544 & 0.0554 & 0.0556 & 0.0272 & 0.2451 \\
\hline
\end{tabular}

FR9 (Market Share) is the most important criterion with the highest entropy weight of 0.2451. The contribution of FR8 (Return of Assets) is minimum (0.0272) for financial efficiency.

\section{CRITIC METHOD}

Standard Deviation: Standard deviations of FRs are determined as discussed in section 6 . Standard deviation, of FRs represent the degree of deviation of variant values for a given criteria of a mean value. Standard Deviation of Financial Ratios are shown in Table-13

Table 13 Standard Deviation of Financial Ratios

\begin{tabular}{|c|c|c|c|c|c|c|c|c|c|}
\hline FRs & FR1 & FR2 & FR3 & FR4 & FR5 & FR6 & FR7 & FR8 & FR9 \\
\hline Standard deviation & 0.1300 & 0.1662 & 0.1832 & 0.1971 & 0.1577 & 0.1147 & 0.1713 & 0.1414 & 0.2601 \\
\hline
\end{tabular}

From Table-13, it is observed that highest standard deviation is obtained with FR4 (Return of Stock Holder Equity). FR6 (Operating income ratio) is obtained low standard deviation. A high standard deviation implies that, on average, data points are all pretty far from the average. A low standard deviation means most points are very close to the average.

Correlation Coefficient Matrix: Linear correlation coefficients between the financial ratios are determined as discussed in section 6 . The correlation coefficient matrix is shown in Table14.

Table 14 Correlation coefficient of financial ratios

\begin{tabular}{|l|c|r|r|r|r|r|r|r|r|}
\hline FRs & FR1 & \multicolumn{1}{|c|}{ FR2 } & \multicolumn{1}{|c|}{ FR3 } & \multicolumn{1}{|c|}{ FR4 } & \multicolumn{1}{c|}{ FR5 } & \multicolumn{1}{c|}{ FR6 } & \multicolumn{1}{c|}{ FR7 } & FR8 & \multicolumn{1}{c|}{ FR9 } \\
\hline FR1 & 1.0000 & -0.0166 & -0.0255 & -0.1713 & -0.3145 & -0.3023 & -0.2540 & -0.3880 & -0.3880 \\
\hline FR2 & -0.0166 & 1.0000 & 0.0516 & -0.0701 & 0.2870 & -0.2432 & 0.1785 & 0.0315 & -0.0706 \\
\hline FR3 & -0.0255 & 0.0516 & 1.0000 & 0.3784 & 0.1391 & 0.1518 & 0.2278 & 0.1986 & 0.2613 \\
\hline FR4 & -0.1713 & -0.0701 & 0.3784 & 1.0000 & 0.3131 & 0.3204 & 0.4564 & 0.4725 & 0.8321 \\
\hline FR5 & -0.3145 & 0.2870 & 0.1391 & 0.3131 & 1.0000 & 0.1948 & 0.6336 & 0.5066 & 0.2326 \\
\hline FR6 & -0.3023 & -0.2432 & 0.1518 & 0.3204 & 0.1948 & 1.0000 & 0.0537 & 0.5222 & 0.3197 \\
\hline FR7 & -0.2540 & 0.1785 & 0.2278 & 0.4564 & 0.6336 & 0.0537 & 1.0000 & 0.6619 & 0.3646 \\
\hline FR8 & -0.3880 & 0.0315 & 0.1986 & 0.4725 & 0.5066 & 0.5222 & 0.6619 & 1.0000 & 0.4088 \\
\hline FR9 & -0.1760 & -0.0706 & 0.2613 & 0.8321 & 0.2326 & 0.3197 & 0.3646 & 0.4088 & 1.0000 \\
\hline
\end{tabular}

Correlation coefficients are used in statistics to measure how strong a relationship is between two variables. 1 indicates a strong positive relationship. -1 indicates a strong negative relationship. A result of zero indicates no relationship at all. From table 4.10 it is observed that FR1 is showing negative correlation with all other financial ratios. There is strong correlation of 0.3880 is observed between, FR1- FR8 and FR1-FR9.

FR2 is showing negative correlation with FR1, FR4, and FR6 and FR9. There is strong correlation of 0.2870 is observed between, FR1 and FR5. FR3 is showing highest positive correlation (0.3784) with FR4. FR5 is showing highest positive correlation (0.6336) with FR7. FR6 is showing highest positive correlation (0.6619) with FR8. FR9 is showing highest positive correlation (0.8321) with FR4

Measure of Conflict: Measure of conflict is determined as discussed in section 6 and shown in Table-15.

Table 15 Measure of conflict

\begin{tabular}{|c|c|c|c|c|c|c|c|c|c|}
\hline FRs & FR1 & FR2 & FR3 & FR4 & FR5 & FR6 & FR7 & FR8 & FR9 \\
\hline Measure of conflict & 9.6483 & 7.8218 & 6.6168 & 5.4685 & 6.0077 & 6.9828 & 5.6776 & 5.5861 & 6.0395 \\
\hline
\end{tabular}


From Table-4.3.3, it is observed that there is a high measure of conflict of 9.6483 with FR1 and low measure of conflict of 5.4685 is obtained with FR4.

Amount of information in the FRs: The amount of information contained in the FR is determined as discussed in section 6. The values of Amount of information in the FRs are shown in Table16.

Table 16 Information content of FRs

\begin{tabular}{|c|c|c|c|c|c|c|c|c|c|}
\hline FRs & FR1 & FR2 & FR3 & FR4 & FR5 & FR6 & FR7 & FR8 & FR9 \\
\hline $\mathrm{C}_{\mathrm{j}}$ & 1.2539 & 1.3046 & 1.2123 & 1.0777 & 0.9472 & 0.8007 & 0.9726 & 0.7897 & 1.5706 \\
\hline
\end{tabular}

From Table-16, it is observed that, FR9 is obtained the highest value of $C_{j}(1.5706)$. Hence FR9 transmits the largest information and it has the highest relative importance for the decisionmaking process.

Relative weights of FRs: Relative weights of FRs is obtained as discussed in section 6 and the relative weights of FRS is show in Table-17.

Table 17 Relative weights of FRs

\begin{tabular}{|c|c|c|c|c|c|c|c|c|c|}
\hline FRs & FR1 & FR2 & FR3 & FR4 & FR5 & FR6 & FR7 & FR8 & FR9 \\
\hline $\mathrm{w}_{\mathrm{j}}$ & 0.1263 & 0.1314 & 0.1221 & 0.1085 & 0.0954 & 0.0806 & 0.0979 & 0.0795 & 0.1582 \\
\hline
\end{tabular}

From Table-17, it is observed that highest weight of 0.1582 is obtained with FR9 and the lowest weight $(0.0795)$ is obtained with FR8. The relative importance order of FRs is is presented below.

Relative importance of FRs: FR9 $>$ FR2 $>$ FR1 $>$ FR3 $>$ FR4 $>$ FR7 $>$ FR5 $>$ FR6 $>$ FR8.

\section{COMPARISON OF RELATIVE WEIGHTS}

In this paper, three objective rating methods namely: MLP, EM and CRITIC methods are proposed for determination of relative weights of financial ratios in determining the financial efficiency of software manufacturing organizations. Comparison of relative weights obtained by the proposed methods are compared and presented in Table-18.

Table 18 Comparison of relative weights

\begin{tabular}{|l|l|l|l|}
\hline \multirow{2}{*}{ FRs } & \multicolumn{3}{|c|}{ Methods } \\
\cline { 2 - 4 } & \multicolumn{1}{|c|}{ MLP } & \multicolumn{1}{|c|}{ EM } & \multicolumn{1}{c|}{ CRITIC } \\
\hline FR1 & $0.118(\mathrm{III})$ & $0.2345(\mathrm{II})$ & $0.1263(\mathrm{III})$ \\
\hline FR2 & $0.108(\mathrm{~V})$ & $0.0304(\mathrm{VIII})$ & $0.1314(\mathrm{II})$ \\
\hline FR3 & $0.132(\mathrm{II})$ & $0.1125(\mathrm{IV})$ & $0.1221(\mathrm{IV})$ \\
\hline FR4 & $0.109(\mathrm{IV})$ & $0.1749(\mathrm{III})$ & $0.1085(\mathrm{~V})$ \\
\hline FR5 & $0.104(\mathrm{VI})$ & $0.0544(\mathrm{VII})$ & $0.0954(\mathrm{VII})$ \\
\hline FR6 & $0.095(\mathrm{VIII})$ & $0.0554(\mathrm{VI})$ & $0.0806(\mathrm{VIII})$ \\
\hline FR7 & $0.1(\mathrm{VII})$ & $0.0556(\mathrm{~V})$ & $0.0979(\mathrm{VI})$ \\
\hline FR8 & $0.092(\mathrm{IX})$ & $0.0272(\mathrm{IX})$ & $0.0795(\mathrm{IX})$ \\
\hline FR9 & $0.142(\mathrm{I})$ & $0.2451(\mathrm{I})$ & $0.1582(\mathrm{I})$ \\
\hline
\end{tabular}

From the results shown in Table-18, it is observed that the proposed methods are consistent in prioritizing the FRs of FR9, FR8 in contributing the highest and lowest importance on the financial efficiency. Similar ranking is obtained based on relative importance of FRs on Financial efficiency for other financial ratios.

\section{CORRELATION OF THE METHODS}

Correlations between the three proposed in determining the relative weights methods are computed. Correlation coefficients are shown in Table-19. 
From the correlations between objective weight methods, it is observed that there is high significant positive correlation $(\geq 0.890)$ is existed between MLP and CRITIC methods. The pvalues for the individual hypothesis tests of the correlations are being shown in brackets. Since all the $p$-values are less than or equal to 0.05 , there is sufficient evidence at $\alpha=0.05$ that there exists significant correlation between the three methods.

Table 19 Correlation coefficients

\begin{tabular}{|l|c|c|c|}
\hline Method & MLP & EM & CRITIC \\
\hline MLP & 1.000 & $0.761(0.017)$ & $0.890(0.001)$ \\
\hline EM & $0.761(0.017)$ & 1.000 & $0.696(0.037)$ \\
\hline CRITIC & $0.890(0.001)$ & $0.696(0.037)$ & 1.000 \\
\hline
\end{tabular}

\section{AVERAGE RELATIVE WEIGHTS}

Average relative weights of financial ratios are obtained by taking the average of the weights obtained from the proposed methods. Average Relative weights of financial ratios based on the data on financial ratio from FY2013-14 to 2017-18 are determined and average relative weights of financial ratios are shown in Table-20.

Table 20 Average relative weights of financial ratios

\begin{tabular}{|c|c|c|c|c|c|c|c|c|c|}
\hline FRs & FR1 & FR2 & FR3 & FR4 & FR5 & FR6 & FR7 & FR8 & FR9 \\
\hline $\begin{array}{c}\text { Average relative } \\
\text { weight }\end{array}$ & 0.1596 & 0.0899 & 0.1255 & 0.1308 & 0.0846 & 0.0770 & 0.0845 & 0.0663 & 0.1818 \\
\hline
\end{tabular}

Order of Average relative weights of FRs is presented below.

Relative weights of FRs: FR9 $(0.1818)>\operatorname{FR} 1(0.1596)>\operatorname{FR} 4(0.1308)>\operatorname{FR} 3(0.1255)>$ $\operatorname{FR} 2(0.0899)>\operatorname{FR} 5(0.0846)>\operatorname{FR} 7(0.0845)>\operatorname{FR} 6(0.0770)$.

Relative weights of financial ratios obtained by the proposed methods and average relative weights are presented in Figure 1.

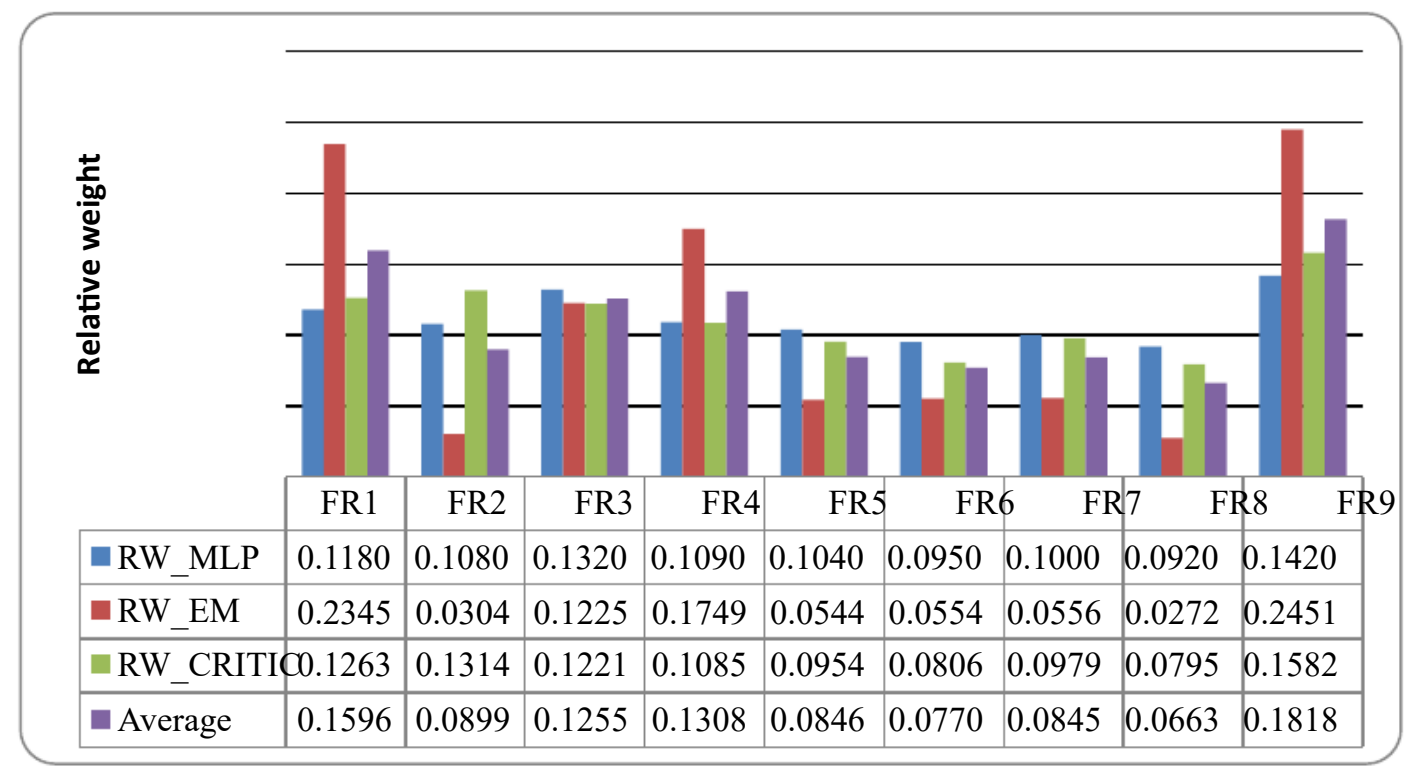

Figure 1 Average relative weights 


\section{CONCLUDING REMARKS}

The aim of this paper is to determine the relative weights of the financial ratios through MLP of artificial neural networks in predicting financial efficiency, based on financial ratios data collected from annual reports of eighteen software companies during $1^{\text {st }} \mathrm{FY}$ to $5^{\text {th }} \mathrm{FY}$. Also, the results of the neural network analysis are compared with entropy measurement method and CRITIC method. Multilayer perceptron neural networks were trained, to predict financial efficiency also.

The classification accuracy rate of multilayer perception was very high, with $100 \%$. The results also showed that MLP of ANN is the most powerful predictors of financial efficiency. Although future work will need to validate these findings in larger and more diverse samples, there is strong evidence that the proposed model can be used effectively to predict financial efficiency of business organizations in general and software companies in particular and to help the management to design interventions that increase the financial efficiency.

\section{REFERENCES}

[1] Hsiang-Hsi Liu1, Tser-Yieth Chen1, Yung-Ho Chiu2, Fu-Hsiang Kuo, A Comparison of Three-Stage DEA and Artificial Neural Network on the Operational Efficiency of SemiConductor Firms in Taiwan, Modern Economy, Vol. 4,2013, pp. 20-31

[2] Krzysztof Piasecki and Aleksandra Wójcicka-Wójtowicz, apacity Of Neural Networks And Discriminant Analysis In Classifying Potential Debtors, Folia Oeconomica Stetinensia, pp.129-142, DOI: 10.1515/foli-2017-0023, 2017

[3] Nor Mazlina Abu Bakar and Izah Mohd Tahir, Applying Multiple Linear Regression and Neural Network to Predict Bank Performance, International Business Research,Vol.2, No.4,2009, pp.176-183

[4] Ayan Mukhopadhyay1,Suman Tiwari2, Ankit Narsaria3and Bhaskar Roy Karmaker, A New Approach to Predicting Bankruptcy: Combining DEA and Multi-Layer Perceptron, IJCSI International Journal of Computer Science Issues, Vol. 9, No.2,2012, pp.71-78

[5] Olanrewaju A Oludolapo, Adisa A Jimoh and Pule A Kholopane, Comparing performance of MLP and RBF neural network models for predicting South Africa's energy consumption, Journal of Energy in Southern Africa, Vol. 23, No.3, 2012, pp.40-46

[6] Mehdi Alinezhad Sarokolaei+, Parisa Alinezhad and Mohsen Akbari Khosroshahi, A Comparative Study of Iranian Banks' Efficiency by Using Artificial Neural Networks and Multi-Linear Regression, $2^{\text {nd }}$ International Conference on Management and Artificial Intelligence, Singapore, Vol.35,2012, pp.80-83

[7] Elena Yurevna Sidorova, Oleg Igorevich Kalinskii, Gennadii Alekseevich Molchanov and Nadegda Vasilevna Shmeleva, Metallurgical Enterprises Goodwill Management on the Basis of a Rating Evaluation Using the Optimal Financial Ratios, International Journal of Mechanical Engineering and Technology, 9(12), 2018, pp. 1129-1140

[8] Viju Raghupathi and Wullianallur Raghupathi, Neural Network Analysis of Treatment Quality and Efficiency of Hospitals, Journal of Health \& Medical Informatics, Vol.6,No.6,2015, pp.1-12

[9] Mahmoud H. Al-Osaimy, A Neural Networks System for Predicting Islamic Banks Performance, Journal of King Abdul Aziz University: Econ. \& Adm., Vol. 11, 1998, pp. $33-46$

[10] Satish Sharma and Mikhail Shebalkov, Application of Neural Network and Simulation Modeling to Evaluate Russian Banks' Performance, Journal of Applied Finance \& Banking, Vol. 3, No. 5, 2013, pp. 19-37 
[11] Faruk Erinci and Serhat Duranay, Predicting the Performance of Turkish Commercial Banks with Artificial Neural Networks, Recent Research in Interdisciplinary Sciences, Chapter46, pp. 603-618, 2016

\section{APPENDIX}

Table-A.1 Data belonging to financial ratios for the $1^{\text {st }}$ year

\begin{tabular}{|c|c|c|c|c|c|c|c|c|c|}
\hline $\begin{array}{l}\text { Software } \\
\text { compan } \\
\text { y }\end{array}$ & $\begin{array}{l}\text { Stockholder } \\
\text { s equity } \\
\text { ratio (FR1) }\end{array}$ & $\begin{array}{l}\text { Turnover } \\
\text { rate of } \\
\text { accounts } \\
\text { receivable } \\
\text { s } \\
\text { (FR2) }\end{array}$ & $\begin{array}{l}\text { Turnover } \\
\text { rate of } \\
\text { inventory } \\
\text { (FR3) }\end{array}$ & $\begin{array}{l}\text { Return of } \\
\text { stockholde } \\
\text { r equity } \\
\text { (FR4) }\end{array}$ & $\begin{array}{l}\text { Quick } \\
\text { Ratio } \\
\text { (FR5) }\end{array}$ & $\begin{array}{l}\text { Operatin } \\
\text { g income } \\
\text { ratio } \\
\text { (FR6) }\end{array}$ & $\begin{array}{l}\text { Operatin } \\
\text { g cash } \\
\text { flow ratio } \\
\text { (FR7) }\end{array}$ & $\begin{array}{l}\text { Return } \\
\text { of } \\
\text { Assets } \\
\text { (FR8) }\end{array}$ & $\begin{array}{l}\text { Marke } \\
\text { t Share } \\
\text { (FR9) }\end{array}$ \\
\hline SWC1 & 0.1298 & 6.1418 & 981.2177 & -0.6244 & $\begin{array}{c}0.377 \\
4\end{array}$ & 0.0697 & 0.0404 & $\begin{array}{c}- \\
0.0811 \\
\end{array}$ & 0.0052 \\
\hline SWC2 & 0.0047 & 6.3151 & 136.2825 & 46.4965 & $\begin{array}{c}2.151 \\
8\end{array}$ & 0.2500 & 0.6807 & 0.2166 & 0.1274 \\
\hline SWC3 & 0.0050 & 6.4964 & $\begin{array}{c}3016.000 \\
0\end{array}$ & 37.2587 & $\begin{array}{c}3.836 \\
8\end{array}$ & 0.2671 & 0.7710 & 0.1861 & 0.1988 \\
\hline SWC4 & 0.0172 & 4.7198 & \begin{tabular}{|c|}
1350.682 \\
2 \\
\end{tabular} & 6.7102 & $\begin{array}{c}1.519 \\
8 \\
\end{array}$ & 0.1402 & 0.2634 & 0.1153 & 0.0107 \\
\hline SWC5 & 0.0147 & 6.9437 & \begin{tabular}{|c|}
1299.936 \\
5
\end{tabular} & 4.6751 & $\begin{array}{c}2.546 \\
8\end{array}$ & 0.0976 & 0.4650 & 0.0687 & 0.0037 \\
\hline SWC6 & 0.0199 & 5.7679 & \begin{tabular}{|c|}
1301.411 \\
5
\end{tabular} & 10.8106 & $\begin{array}{c}3.826 \\
1\end{array}$ & 0.2012 & 0.7064 & 0.2147 & 0.0120 \\
\hline SWC7 & 0.0300 & 3.6304 & $\begin{array}{c}1299.808 \\
9\end{array}$ & 1.4404 & $\begin{array}{c}2.436 \\
1\end{array}$ & 0.1694 & 0.1465 & 0.0432 & 0.0103 \\
\hline SWC8 & 0.0331 & 4.5276 & 417.7281 & 3.7979 & $\begin{array}{c}2.703 \\
6\end{array}$ & 0.1537 & 0.2895 & 0.1256 & 0.0091 \\
\hline SWC9 & 0.0043 & 5.3117 & \begin{tabular}{|c|}
1307.661 \\
8
\end{tabular} & 32.3109 & $\begin{array}{c}9.247 \\
0\end{array}$ & 0.3740 & 0.7097 & 0.1398 & 0.0148 \\
\hline SWC10 & 0.0257 & 6.0927 & $\begin{array}{c}1300.962 \\
5\end{array}$ & 6.2320 & $\begin{array}{c}3.436 \\
7\end{array}$ & 0.2482 & 0.8481 & 0.1601 & 0.0066 \\
\hline SWC11 & 0.0221 & 3.3705 & \begin{tabular}{|c|}
1297.356 \\
2
\end{tabular} & 1.7584 & $\begin{array}{c}0.308 \\
9\end{array}$ & 0.3276 & 0.2878 & 0.0389 & 0.0099 \\
\hline SWC12 & 0.0427 & 5.0058 & 146.0758 & 2.4187 & $\begin{array}{c}3.953 \\
1\end{array}$ & 0.1166 & 0.6923 & 0.1034 & 0.0018 \\
\hline SWC13 & 0.0160 & 8.9554 & $\begin{array}{c}1466.290 \\
0\end{array}$ & 7.3926 & $\begin{array}{c}2.257 \\
0\end{array}$ & 0.0636 & 0.4550 & 0.1180 & 0.0062 \\
\hline SWC14 & 0.0029 & 5.0615 & $\begin{array}{c}3116.423 \\
0\end{array}$ & 97.8397 & $\begin{array}{c}3.209 \\
8\end{array}$ & 0.3075 & 0.8360 & 0.2854 & 0.3244 \\
\hline SWC15 & 0.0792 & 5.3193 & \begin{tabular}{|c|}
4098.000 \\
0
\end{tabular} & 2.4120 & \begin{tabular}{|c|}
1.872 \\
7 \\
\end{tabular} & 0.1773 & 0.7977 & 0.1911 & 0.0031 \\
\hline SWC16 & 0.0146 & 6.2134 & \begin{tabular}{|c|}
1405.634 \\
6 \\
\end{tabular} & 12.9713 & $\begin{array}{c}1.974 \\
4\end{array}$ & 0.2225 & 0.2496 & 0.1900 & 0.0746 \\
\hline SWC17 & 0.0099 & 5.3555 & 121.6289 & 16.1199 & $\begin{array}{c}2.223 \\
2\end{array}$ & 0.2219 & 0.5476 & 0.1599 & 0.1722 \\
\hline SWC18 & 0.0295 & 6.7336 & 16.9201 & 5.4265 & $\begin{array}{c}1.969 \\
6\end{array}$ & 0.1534 & 0.5656 & 0.1598 & 0.0093 \\
\hline
\end{tabular}

Table-A.2 Data belonging to financial ratios for the $2^{\text {nd }}$ year

\begin{tabular}{|c|c|c|c|c|c|c|c|c|c|}
\hline $\begin{array}{l}\text { Softwar } \\
\text { e } \\
\text { compan } \\
y\end{array}$ & $\begin{array}{c}\text { Stockholders } \\
\text { equity ratio } \\
\text { (FR1) }\end{array}$ & $\begin{array}{c}\text { Turnover rate } \\
\text { of accounts } \\
\text { receivables } \\
\text { (FR2) }\end{array}$ & $\begin{array}{c}\text { Turnover rate } \\
\text { of inventory } \\
\text { (FR3) }\end{array}$ & $\begin{array}{c}\text { Return of } \\
\text { stockholder } \\
\text { equity } \\
\text { (FR4) }\end{array}$ & $\begin{array}{l}\text { Quick } \\
\text { Ratio } \\
\text { (FR5) }\end{array}$ & $\begin{array}{l}\text { Operati } \\
\text { ng } \\
\text { income } \\
\text { ratio } \\
\text { (FR6) }\end{array}$ & $\begin{array}{c}\text { Operating } \\
\text { cash flow } \\
\text { ratio } \\
\text { (FR7) }\end{array}$ & $\begin{array}{c}\text { Return } \\
\text { of } \\
\text { Assets } \\
\text { (FR8) }\end{array}$ & $\begin{array}{c}\text { Market } \\
\text { Share } \\
\text { (FR9) }\end{array}$ \\
\hline SWC1 & 0.1660 & 6.9077 & 836.6929 & -1.6170 & 0.4026 & 0.1284 & -0.0290 & -0.2684 & 0.004693 \\
\hline
\end{tabular}




\begin{tabular}{|c|c|c|c|c|c|c|c|c|c|}
\hline SWC2 & 0.0080 & 6.0060 & 201.6980 & 26.0209 & 2.4413 & 0.2309 & 0.5317 & 0.2073 & 0.128143 \\
\hline SWC3 & 0.0086 & 5.9033 & 1301.0146 & 21.6294 & 3.4819 & 0.2791 & 0.5263 & 0.1857 & 0.186165 \\
\hline SWC4 & 0.0165 & 4.3579 & 202.6233 & 6.3012 & 1.5730 & 0.1085 & 0.5998 & 0.1038 & 0.010439 \\
\hline SWC5 & 0.0136 & 8.0919 & 1299.7027 & 1.5732 & 2.3440 & 0.0468 & 0.2834 & 0.0213 & 0.003535 \\
\hline SWC6 & 0.0315 & 5.4938 & 1300.7675 & 6.4074 & 3.2675 & 0.1991 & 0.9353 & 0.2020 & 0.012436 \\
\hline SWC7 & 0.0282 & 8.2604 & 1299.9875 & 3.2103 & 2.5911 & 0.1496 & 0.4397 & 0.0905 & 0.020233 \\
\hline SWC8 & 0.0303 & 4.0544 & 297.3188 & 1.8688 & 2.2119 & 0.1391 & 0.3963 & 0.0566 & 0.008284 \\
\hline SWC9 & 0.0067 & 6.0902 & 1299.1862 & 28.1806 & 1.8961 & 0.3974 & 0.3751 & 0.1901 & 0.013634 \\
\hline SWC10 & 0.0444 & 5.7189 & 1301.0629 & 3.6329 & 3.5237 & 0.2064 & 0.7971 & 0.1614 & 0.006603 \\
\hline SWC11 & 0.0191 & 3.4431 & 1297.4939 & 1.5197 & 0.4284 & 0.3517 & 0.2067 & 0.0290 & 0.012847 \\
\hline SWC12 & 0.0382 & 5.2617 & 385.7953 & 5.6026 & 4.6112 & -0.1447 & 1.7252 & 0.2139 & 0.001494 \\
\hline SWC13 & 0.0130 & 6.4877 & 354.6815 & 12.7091 & 2.0666 & 0.0997 & 0.2163 & 0.1654 & 0.005873 \\
\hline SWC14 & 0.0027 & 4.8954 & 4486.3619 & 101.3539 & 2.6936 & 0.2587 & 0.8544 & 0.2695 & 0.330468 \\
\hline SWC15 & 0.0662 & 5.4860 & 4635.4483 & 3.3044 & 1.9887 & 0.2087 & 0.7669 & 0.2188 & 0.002966 \\
\hline SWC16 & 0.0242 & 4.7352 & 1074.5364 & 5.4698 & 2.0811 & 0.1854 & 0.3548 & 0.1324 & 0.078983 \\
\hline SWC17 & 0.0083 & 5.3047 & 102.6374 & 17.5428 & 2.1787 & 0.2194 & 0.5451 & 0.1459 & 0.163931 \\
\hline SWC18 & 0.0253 & 6.5412 & 18.0122 & 5.9686 & 2.0244 & 0.1475 & 0.7641 & 0.1510 & 0.009273 \\
\hline
\end{tabular}

Table-A.3: Data belonging to financial ratios for the $3^{\text {rd }}$ year

\begin{tabular}{|c|c|c|c|c|c|c|c|c|c|}
\hline $\begin{array}{c}\text { Softwar } \\
\text { e } \\
\text { compan } \\
\mathbf{y}\end{array}$ & $\begin{array}{c}\text { Stockholders } \\
\text { equity ratio } \\
\text { (FR1) }\end{array}$ & $\begin{array}{c}\text { Turnover rate } \\
\text { of accounts } \\
\text { receivables } \\
\text { (FR2) }\end{array}$ & $\begin{array}{c}\text { Turnover rate } \\
\text { of inventory } \\
\text { (FR3) }\end{array}$ & $\begin{array}{c}\text { Return of } \\
\text { stockholde } \\
\text { requity } \\
\text { (FR4) }\end{array}$ & $\begin{array}{c}\text { Quick } \\
\text { Ratio } \\
\text { (FR5) }\end{array}$ & $\begin{array}{c}\text { Operating } \\
\text { income } \\
\text { ratio } \\
\text { (FR6) }\end{array}$ & $\begin{array}{c}\text { Operating } \\
\text { cash flow } \\
\text { ratio } \\
\text { (FR7) }\end{array}$ & $\begin{array}{c}\text { Return } \\
\text { of } \\
\text { Assets } \\
\text { (FR8) }\end{array}$ & $\begin{array}{c}\text { Market } \\
\text { Share } \\
\text { (FR9) }\end{array}$ \\
\hline SWC1 & 0.4034 & 6.2637 & 1689.2743 & -0.8610 & 0.5238 & -0.6959 & 0.3602 & -0.3473 & 0.003574 \\
\hline SWC2 & 0.0072 & 4.3669 & 116.0055 & 19.8611 & 2.4697 & 0.2137 & 0.3496 & 0.1421 & 0.098853 \\
\hline SWC3 & 0.0152 & 5.9346 & 1302.2510 & 11.7911 & 4.5542 & 0.2735 & 0.7370 & 0.1790 & 0.198242 \\
\hline SWC4 & 0.0171 & 4.6595 & 91.6409 & 7.4767 & 1.9310 & 0.1348 & 0.7307 & 0.1279 & 0.010237 \\
\hline SWC5 & 0.0269 & 4.5697 & 1300.8451 & 1.1948 & 3.3349 & 0.0287 & 0.2913 & 0.0321 & 0.001673 \\
\hline SWC6 & 0.0506 & 5.5994 & 1299.7556 & 3.2926 & 2.3899 & 0.1757 & 0.4914 & 0.1666 & 0.014836 \\
\hline SWC7 & 0.0295 & 9.5450 & 2545.3073 & 3.0045 & 4.3873 & 0.1419 & 0.9124 & 0.0885 & 0.019306 \\
\hline SWC8 & 0.0263 & 4.4945 & 503.1328 & 4.4118 & 1.8866 & 0.1755 & 0.4832 & 0.1160 & 0.008534 \\
\hline SWC9 & 0.0074 & 5.7670 & 1302.2844 & 24.7672 & 4.5831 & 0.3916 & 0.6701 & 0.1828 & 0.013116 \\
\hline SWC10 & 0.0373 & 5.8828 & 1301.0457 & 3.4663 & 3.5089 & 0.1693 & 0.5257 & 0.1293 & 0.007341 \\
\hline SWC11 & 0.0172 & 2.3494 & 1297.4821 & 1.1296 & 0.4181 & 0.3021 & 0.2125 & 0.0194 & 0.012063 \\
\hline SWC12 & 0.0278 & 5.8140 & 323.5205 & 11.6416 & 4.3087 & 0.0224 & 1.8110 & 0.3235 & 0.001534 \\
\hline SWC13 & 0.0106 & 5.8396 & 201.6851 & 15.0751 & 1.6740 & 0.0989 & 0.4587 & 0.1599 & 0.006161 \\
\hline SWC14 & 0.0022 & 4.8818 & 4862.4259 & 123.1980 & 4.2836 & 0.2824 & 1.0727 & 0.2723 & 0.344937 \\
\hline SWC15 & 0.0514 & 5.8231 & 5706.8276 & 4.9714 & 2.2688 & 0.2304 & 0.5511 & 0.2557 & 0.003414 \\
\hline SWC16 & 0.0193 & 4.8275 & 685.9136 & 6.8723 & 2.2918 & 0.1612 & 0.4568 & 0.1327 & 0.084116 \\
\hline SWC17 & 0.0066 & 5.3613 & 79.0081 & 18.0285 & 2.0085 & 0.2107 & 0.4899 & 0.1191 & 0.162693 \\
\hline SWC18 & 0.0233 & 5.9399 & 20.2269 & 6.4878 & 2.3456 & 0.1486 & 0.5056 & 0.1509 & 0.009372 \\
\hline
\end{tabular}

Table-A.4: Data belonging to financial ratios for the $4^{\text {th }}$ year

\begin{tabular}{|c|c|c|c|c|c|c|c|c|c|}
\hline $\begin{array}{c}\text { Softwar } \\
\mathbf{e} \\
\text { compan } \\
\mathbf{y}\end{array}$ & $\begin{array}{c}\text { Stockholders } \\
\text { equity ratio } \\
\text { (FR1) }\end{array}$ & $\begin{array}{c}\text { Turnover rate } \\
\text { of accounts } \\
\text { receivables } \\
\text { (FR2) }\end{array}$ & $\begin{array}{c}\text { Turnover rate } \\
\text { of inventory } \\
\text { (FR3) }\end{array}$ & $\begin{array}{c}\text { Return of } \\
\text { stockhold } \\
\text { er equity } \\
\text { (FR4) }\end{array}$ & $\begin{array}{c}\text { Quick } \\
\text { Ratio } \\
\text { (FR5) }\end{array}$ & $\begin{array}{c}\text { Operating } \\
\text { income } \\
\text { ratio } \\
\text { (FR6) }\end{array}$ & $\begin{array}{c}\text { Operating } \\
\text { cash flow } \\
\text { ratio } \\
\text { (FR7) }\end{array}$ & $\begin{array}{c}\text { Retur } \\
\text { n of } \\
\text { Assets } \\
\text { (FR8) }\end{array}$ & $\begin{array}{c}\text { Market } \\
\text { Share } \\
\text { (FR9) }\end{array}$ \\
\hline SWC1 & 0.7223 & 5.2397 & 973.2874 & 0.0800 & 0.4050 & 0.1564 & 0.1149 & 0.0578 & 0.002826 \\
\hline SWC2 & 0.0062 & 5.9378 & 137.5962 & 30.1965 & 2.3498 & 0.2183 & 0.7172 & 0.1868 & 0.133911 \\
\hline SWC3 & 0.0136 & 5.7910 & 1302.3524 & 12.5463 & 4.6421 & 0.2717 & 0.7663 & 0.1708 & 0.192792 \\
\hline SWC4 & 0.0148 & 4.5157 & 73.0530 & 6.3366 & 1.9498 & 0.1050 & 0.2847 & 0.0938 & 0.009346 \\
\hline SWC5 & 0.0160 & 6.1482 & 1299.4242 & 2.7725 & 2.1025 & 0.0812 & 0.2177 & 0.0443 & 0.001577 \\
\hline SWC6 & 0.0491 & 5.6034 & 1300.2779 & 2.4917 & 2.8430 & 0.1345 & 0.8781 & 0.1224 & 0.014741 \\
\hline SWC7 & 0.0285 & 9.5181 & 2494.1024 & 3.7619 & 4.4497 & 0.1586 & 0.6872 & 0.1073 & 0.017106 \\
\hline SWC8 & 0.0247 & 5.2965 & 7740.3333 & 4.0733 & 2.0441 & 0.1713 & 0.6070 & 0.1004 & 0.007888 \\
\hline SWC9 & 0.0070 & 5.7150 & 1299.1445 & 27.9112 & 1.8600 & 0.3908 & 0.4030 & 0.1961 & 0.012461 \\
\hline SWC10 & 0.0338 & 6.3758 & 1301.5167 & 3.7684 & 3.9173 & 0.1583 & 0.6165 & 0.1274 & 0.008103 \\
\hline SWC11 & 0.0156 & 1.9229 & 1297.6098 & 1.0150 & 0.5288 & 0.3044 & -0.0278 & 0.0158 & 0.008952 \\
\hline
\end{tabular}


Some Objective Methods for Determining Relative Importance of Financial Ratios

\begin{tabular}{|l|l|l|l|l|l|l|l|l|l|}
\hline SWC12 & 0.0256 & 5.3704 & 337.9028 & 4.9497 & 5.8861 & 0.1069 & 0.2594 & 0.1266 & 0.001315 \\
\hline SWC13 & 0.0087 & 5.4230 & 435.4106 & 15.0723 & 1.7774 & 0.0808 & 0.3342 & 0.1305 & 0.006674 \\
\hline SWC14 & 0.0019 & 5.0532 & 4630.0000 & 133.4467 & 5.1366 & 0.2739 & 1.4336 & 0.2539 & 0.332091 \\
\hline SWC15 & 0.0432 & 5.3794 & 1301.3368 & 5.6127 & 3.7613 & 0.2211 & 0.8859 & 0.2426 & 0.003483 \\
\hline SWC16 & 0.0168 & 5.2467 & 492.2367 & 6.4104 & 2.0357 & 0.1436 & 0.4926 & 0.1079 & 0.082035 \\
\hline SWC17 & 0.0059 & 5.7028 & 94.8469 & 17.4719 & 2.0497 & 0.2042 & 0.5785 & 0.1036 & 0.156095 \\
\hline SWC18 & 0.0209 & 5.6944 & 22.4173 & 5.2345 & 2.5092 & 0.1250 & 0.5587 & 0.1092 & 0.008602 \\
\hline
\end{tabular}

Table-A.5 Data belonging to financial ratios for the $5^{\text {th }}$ year

\begin{tabular}{|c|c|c|c|c|c|c|c|c|c|}
\hline $\begin{array}{c}\text { Softwar } \\
\mathbf{e} \\
\text { compan } \\
\mathbf{y}\end{array}$ & $\begin{array}{c}\text { Stockholders } \\
\text { equity ratio } \\
\text { (FR1) }\end{array}$ & $\begin{array}{c}\text { Turnover rate } \\
\text { of accounts } \\
\text { recivables } \\
\text { (FR2) }\end{array}$ & $\begin{array}{c}\text { Turnover rate } \\
\text { of inventory } \\
\text { (FR3) }\end{array}$ & $\begin{array}{c}\text { Return of } \\
\text { stockholder } \\
\text { equity } \\
\text { (FR4) }\end{array}$ & $\begin{array}{c}\text { Quick } \\
\text { Ratio } \\
\text { (FR5) }\end{array}$ & $\begin{array}{c}\text { Operati } \\
\text { ng } \\
\text { income } \\
\text { ratio } \\
\text { (FR6) }\end{array}$ & $\begin{array}{c}\text { Operating } \\
\text { cash flow } \\
\text { ratio } \\
\text { (FR7) }\end{array}$ & $\begin{array}{c}\text { Return } \\
\text { of } \\
\text { Assets } \\
\text { (FR8) }\end{array}$ & $\begin{array}{c}\text { Market } \\
\text { Share } \\
\text { (FR9) }\end{array}$ \\
\hline SWC1 & 0.9961 & 4.7757 & 874.7225 & 0.0436 & 0.5345 & 0.1572 & 0.1356 & 0.0434 & 0.002695 \\
\hline SWC2 & 0.0058 & 5.6376 & 175.5491 & 31.3705 & 2.4869 & 0.2224 & 0.7369 & 0.1808 & 0.13749 \\
\hline SWC3 & 0.0135 & 5.5390 & 1302.0376 & 14.7325 & 4.3691 & 0.2696 & 0.8507 & 0.1992 & 0.19174 \\
\hline SWC4 & 0.0138 & 4.6083 & 97.9456 & 6.6715 & 2.0681 & 0.1013 & 0.6633 & 0.0923 & 0.009961 \\
\hline SWC5 & 0.0141 & 7.4214 & 1299.6222 & 5.9038 & 2.2742 & 0.1220 & 0.2904 & 0.0833 & 0.002222 \\
\hline SWC6 & 0.0433 & 5.7151 & 1300.1192 & 3.4783 & 2.7053 & 0.1356 & 0.7575 & 0.1505 & 0.014853 \\
\hline SWC7 & 0.0276 & 9.0946 & 1300.8642 & 4.3333 & 3.3514 & 0.1622 & 0.6429 & 0.1194 & 0.017797 \\
\hline SWC8 & 0.0228 & 5.6774 & 8298.0000 & 4.5561 & 1.9668 & 0.1678 & 0.4235 & 0.1038 & 0.008133 \\
\hline SWC9 & 0.0071 & 5.2477 & 1301.6730 & 28.9909 & 4.0529 & 0.4000 & 0.9130 & 0.2070 & 0.01231 \\
\hline SWC10 & 0.0300 & 6.3194 & 1301.5781 & 4.0386 & 3.9706 & 0.1545 & 0.7778 & 0.1210 & 0.008248 \\
\hline SWC11 & 0.0145 & 2.0309 & 1297.6936 & -0.6395 & 0.6016 & 0.2889 & 0.0303 & -0.0092 & 0.007778 \\
\hline SWC12 & 0.0232 & 6.4312 & 1303.9958 & 4.8171 & 6.0674 & 0.1381 & 0.6861 & 0.1120 & 0.001368 \\
\hline SWC13 & 0.0084 & 5.3559 & 1299.2248 & 18.5482 & 1.9296 & 0.0941 & 0.5448 & 0.1561 & 0.006672 \\
\hline SWC14 & 0.0018 & 5.1768 & 3854.8085 & 135.2147 & 4.4735 & 0.2641 & 1.2029 & 0.2430 & 0.334704 \\
\hline SWC15 & 0.0655 & 5.0276 & 1301.6462 & 3.8542 & 4.0296 & 0.2513 & 0.9269 & 0.2524 & 0.003769 \\
\hline SWC16 & 0.0145 & 5.2001 & 410.4457 & 8.6027 & 1.9674 & 0.1530 & 0.3862 & 0.1248 & 0.083667 \\
\hline SWC17 & 0.0116 & 5.5646 & 121.0707 & 8.8448 & 1.9927 & 0.1906 & 0.5226 & 0.1027 & 0.148143 \\
\hline SWC18 & 0.0193 & 5.2878 & 25.0863 & 5.3685 & 2.6411 & 0.1174 & 0.3182 & 0.1039 & 0.00845 \\
\hline
\end{tabular}

Table-A.6:

\begin{tabular}{|c|c|c|c|c|c|c|c|c|c|}
\hline $\begin{array}{c}\text { Softwar } \\
\mathbf{e} \\
\text { compan } \\
\mathbf{y}\end{array}$ & $\begin{array}{c}\text { Stockholde } \\
\text { rs equity } \\
\text { ratio (FR1) }\end{array}$ & $\begin{array}{c}\text { Turnover } \\
\text { rate of } \\
\text { accounts } \\
\text { receivable } \\
\text { s } \\
\text { (FR2) }\end{array}$ & $\begin{array}{c}\text { Turnover } \\
\text { rate of } \\
\text { inventory } \\
\text { (FR3) }\end{array}$ & $\begin{array}{c}\text { Return of } \\
\text { stockhold } \\
\text { er equity } \\
\text { (FR4) }\end{array}$ & $\begin{array}{c}\text { Quick } \\
\text { Ratio } \\
\text { (FR5) }\end{array}$ & $\begin{array}{c}\text { Opera } \\
\text { ing } \\
\text { incom } \\
\text { e ratio } \\
\text { (FR6) }\end{array}$ & $\begin{array}{c}\text { Operatin } \\
\text { g cash } \\
\text { flow ratio } \\
\text { (FR7) }\end{array}$ & $\begin{array}{c}\text { Return } \\
\text { of } \\
\text { Assets } \\
\text { (FR8) }\end{array}$ & $\begin{array}{c}\text { Mark } \\
\text { et } \\
\text { Share } \\
\text { (FR9) }\end{array}$ \\
\hline SWC1 & 1.0000 & 0.4962 & 0.2363 & 0.0465 & 0.0077 & 0.0199 & 0.0000 & 0.0000 & 0.0104 \\
\hline SWC2 & 0.0137 & 0.5272 & 0.0292 & 0.5028 & 0.2062 & 0.6004 & 0.7927 & 0.8123 & 0.3895 \\
\hline SWC3 & 0.0164 & 0.5597 & 0.7349 & 0.4134 & 0.3947 & 0.6556 & 0.9045 & 0.7288 & 0.6106 \\
\hline SWC4 & 0.1124 & 0.2416 & 0.3268 & 0.1175 & 0.1355 & 0.2468 & 0.2761 & 0.5357 & 0.0275 \\
\hline SWC5 & 0.0928 & 0.6398 & 0.3144 & 0.0978 & 0.2504 & 0.1095 & 0.5257 & 0.4087 & 0.0057 \\
\hline SWC6 & 0.1335 & 0.4293 & 0.3147 & 0.1572 & 0.3935 & 0.4434 & 0.8246 & 0.8071 & 0.0316 \\
\hline SWC7 & 0.2134 & 0.0465 & 0.3144 & 0.0665 & 0.2380 & 0.3409 & 0.1315 & 0.3391 & 0.0263 \\
\hline SWC8 & 0.2377 & 0.2072 & 0.0982 & 0.0893 & 0.2679 & 0.2902 & 0.3085 & 0.5640 & 0.0227 \\
\hline SWC9 & 0.0111 & 0.3476 & 0.3163 & 0.3654 & 1.0000 & 1.0000 & 0.8287 & 0.6026 & 0.0404 \\
\hline SWC10 & 0.1795 & 0.4874 & 0.3146 & 0.1129 & 0.3499 & 0.5947 & 1.0000 & 0.6581 & 0.0149 \\
\hline SWC11 & 0.1515 & 0.0000 & 0.3137 & 0.0696 & 0.0000 & 0.8504 & 0.3064 & 0.3274 & 0.0251 \\
\hline SWC12 & 0.3138 & 0.2928 & 0.0316 & 0.0760 & 0.4077 & 0.1708 & 0.8071 & 0.5033 & 0.0000 \\
\hline SWC13 & 0.1028 & 1.0000 & 0.3551 & 0.1241 & 0.2180 & 0.0000 & 0.5133 & 0.5432 & 0.0136 \\
\hline SWC14 & 0.0000 & 0.3028 & 0.7595 & 1.0000 & 0.3245 & 0.7856 & 0.9850 & 1.0000 & 1.0000 \\
\hline SWC15 & 0.6014 & 0.3489 & 1.0000 & 0.0759 & 0.1750 & 0.3664 & 0.9377 & 0.7427 & 0.0039 \\
\hline SWC16 & 0.0924 & 0.5090 & 0.3403 & 0.1782 & 0.1863 & 0.5120 & 0.2590 & 0.7396 & 0.2255 \\
\hline SWC17 & 0.0552 & 0.3554 & 0.0257 & 0.2086 & 0.2142 & 0.5100 & 0.6279 & 0.6576 & 0.5282 \\
\hline SWC18 & 0.2091 & 0.6022 & 0.0000 & 0.0000 & 0.1858 & 0.2893 & 0.6503 & 0.6573 & 0.0231 \\
\hline
\end{tabular}


Table-A.7

\begin{tabular}{|c|c|c|c|c|c|c|c|c|c|}
\hline $\begin{array}{c}\text { Softwar } \\
\text { e } \\
\text { compan } \\
y\end{array}$ & $\begin{array}{c}\text { Stockh } \\
\text { olders } \\
\text { equity } \\
\text { ratio } \\
\text { (FR1) }\end{array}$ & $\begin{array}{l}\text { Turnover rate } \\
\text { of accounts } \\
\text { receivables } \\
\text { (FR2) }\end{array}$ & $\begin{array}{c}\text { Turnover } \\
\text { rate of } \\
\text { inventory } \\
\text { (FR3) }\end{array}$ & $\begin{array}{c}\text { Return } \\
\text { of } \\
\text { stockhol } \\
\text { der } \\
\text { equity } \\
\text { (FR4) }\end{array}$ & $\begin{array}{l}\text { Quick } \\
\text { Ratio } \\
\text { (FR5) }\end{array}$ & $\begin{array}{c}\text { Oper } \\
\text { ating } \\
\text { incom } \\
\text { e } \\
\text { ratio } \\
\text { (FR6) }\end{array}$ & $\begin{array}{c}\text { Operatin } \\
\text { g cash } \\
\text { flow ratio } \\
\text { (FR7) }\end{array}$ & $\begin{array}{c}\text { Retur } \\
\mathbf{n} \text { of } \\
\text { Assets } \\
\text { (FR8) }\end{array}$ & $\begin{array}{c}\text { Marke } \\
\text { t Share } \\
\text { (FR9) }\end{array}$ \\
\hline SWC1 & 1.0000 & 0.7192 & 0.1773 & 0.0000 & 0.0000 & $\begin{array}{c}0.503 \\
9\end{array}$ & 0.0000 & 0.0000 & 0.0097 \\
\hline SWC2 & 0.0325 & 0.5320 & 0.0398 & 0.2684 & 0.4844 & $\begin{array}{c}0.692 \\
8 \\
\end{array}$ & 0.3196 & 0.8844 & 0.3850 \\
\hline SWC3 & 0.0363 & 0.5107 & 0.2779 & 0.2258 & 0.7317 & $\begin{array}{c}0.781 \\
8\end{array}$ & 0.3166 & 0.8443 & 0.5614 \\
\hline SWC4 & 0.0846 & 0.1899 & 0.0400 & 0.0769 & 0.2781 & $\begin{array}{c}0.467 \\
1\end{array}$ & 0.3584 & 0.6920 & 0.0272 \\
\hline SWC5 & 0.0667 & 0.9650 & 0.2776 & 0.0310 & 0.4613 & $\begin{array}{c}0.353 \\
4\end{array}$ & 0.1781 & 0.5386 & 0.0062 \\
\hline SWC6 & 0.1767 & 0.4257 & 0.2778 & 0.0779 & 0.6807 & $\begin{array}{c}0.634 \\
2\end{array}$ & 0.5497 & 0.8745 & 0.0333 \\
\hline SWC7 & 0.1562 & 1.0000 & 0.2776 & 0.0469 & 0.5200 & $\begin{array}{c}0.542 \\
9\end{array}$ & 0.2672 & 0.6672 & 0.0570 \\
\hline SWC8 & 0.1690 & 0.1269 & 0.0605 & 0.0339 & 0.4299 & $\begin{array}{c}0.523 \\
5\end{array}$ & 0.2424 & 0.6041 & 0.0206 \\
\hline SWC9 & 0.0250 & 0.5495 & 0.2775 & 0.2894 & 0.3549 & $\begin{array}{c}1.000 \\
0\end{array}$ & 0.2304 & 0.8525 & 0.0369 \\
\hline SWC10 & 0.2557 & 0.4724 & 0.2779 & 0.0510 & 0.7416 & $\begin{array}{c}0.647 \\
7\end{array}$ & 0.4709 & 0.7990 & 0.0155 \\
\hline SWC11 & 0.1004 & 0.0000 & 0.2771 & 0.0305 & 0.0061 & $\begin{array}{c}0.915 \\
7\end{array}$ & 0.1344 & 0.5528 & 0.0345 \\
\hline SWC12 & 0.2174 & 0.3775 & 0.0797 & 0.0701 & 1.0000 & $\begin{array}{c}0.000 \\
0\end{array}$ & 1.0000 & 0.8966 & 0.0000 \\
\hline SWC13 & 0.0634 & 0.6320 & 0.0729 & 0.1391 & 0.3954 & $\begin{array}{c}0.450 \\
8\end{array}$ & 0.1399 & 0.8065 & 0.0133 \\
\hline SWC14 & 0.0000 & 0.3015 & 0.9677 & 1.0000 & 0.5444 & $\begin{array}{c}0.744 \\
1\end{array}$ & 0.5036 & 1.0000 & 1.0000 \\
\hline SWC15 & 0.3890 & 0.4241 & 1.0000 & 0.0478 & 0.3769 & $\begin{array}{c}0.651 \\
9\end{array}$ & 0.4537 & 0.9057 & 0.0045 \\
\hline SWC16 & 0.1319 & 0.2682 & 0.2288 & 0.0688 & 0.3988 & $\begin{array}{c}0.608 \\
9\end{array}$ & 0.2188 & 0.7451 & 0.2355 \\
\hline SWC17 & 0.0346 & 0.3865 & 0.0183 & 0.1861 & 0.4220 & $\begin{array}{c}0.671 \\
6\end{array}$ & 0.3273 & 0.7702 & 0.4938 \\
\hline SWC18 & 0.1386 & 0.6431 & 0.0000 & 0.0737 & 0.3854 & $\begin{array}{c}0.539 \\
0\end{array}$ & 0.4521 & 0.7797 & 0.0236 \\
\hline
\end{tabular}

Table-A.8

\begin{tabular}{|c|c|c|c|c|c|c|c|c|c|}
\hline $\begin{array}{c}\text { Softwa } \\
\text { re } \\
\text { compa } \\
\text { ny }\end{array}$ & $\begin{array}{c}\text { Stockho } \\
\text { Iders } \\
\text { equity } \\
\text { ratio } \\
\text { (FR1) }\end{array}$ & $\begin{array}{c}\text { Turnover rate } \\
\text { of accounts } \\
\text { receivables } \\
\text { (FR2) }\end{array}$ & $\begin{array}{c}\text { Turnover } \\
\text { rate of } \\
\text { inventory } \\
\text { (FR3) }\end{array}$ & $\begin{array}{c}\text { Return } \\
\text { of } \\
\text { stockhol } \\
\text { der } \\
\text { equity } \\
\text { (FR4) }\end{array}$ & $\begin{array}{c}\text { Quick } \\
\text { Ratio } \\
\text { (FR5) }\end{array}$ & $\begin{array}{c}\text { Operati } \\
\text { ng } \\
\text { income } \\
\text { ratio } \\
\text { (FR6) }\end{array}$ & $\begin{array}{c}\text { Operatin } \\
\text { g cash } \\
\text { fow ratio } \\
\text { (FR7) }\end{array}$ & $\begin{array}{c}\text { Retur } \\
\text { n of } \\
\text { Assets } \\
\text { (FR8) }\end{array}$ & $\begin{array}{c}\text { Marke } \\
\text { t Share } \\
\text { (FR9) }\end{array}$ \\
\hline SWC1 & 1.0000 & 0.5440 & 0.2935 & 0.0000 & 0.0254 & 0.0000 & 0.0924 & 0.0000 & 0.0059 \\
\hline SWC2 & 0.0123 & 0.2804 & 0.0168 & 0.1670 & 0.4926 & 0.8364 & 0.0857 & 0.7296 & 0.2834 \\
\hline SWC3 & 0.0323 & 0.4982 & 0.2254 & 0.1020 & 0.9930 & 0.8914 & 0.3281 & 0.7846 & 0.5728 \\
\hline SWC4 & 0.0371 & 0.3210 & 0.0126 & 0.0672 & 0.3632 & 0.7639 & 0.3242 & 0.7084 & 0.0253 \\
\hline SWC5 & 0.0615 & 0.3086 & 0.2252 & 0.0166 & 0.7003 & 0.6663 & 0.0493 & 0.5656 & 0.0004 \\
\hline SWC6 & 0.1206 & 0.4517 & 0.2250 & 0.0335 & 0.4734 & 0.8014 & 0.1744 & 0.7661 & 0.0387 \\
\hline SWC7 & 0.0679 & 1.0000 & 0.4440 & 0.0312 & 0.9530 & 0.7704 & 0.4378 & 0.6497 & 0.0518 \\
\hline SWC8 & 0.0600 & 0.2981 & 0.0849 & 0.0425 & 0.3526 & 0.8012 & 0.1693 & 0.6906 & 0.0204 \\
\hline
\end{tabular}


Some Objective Methods for Determining Relative Importance of Financial Ratios

\begin{tabular}{|c|c|c|c|c|c|c|c|c|c|}
\hline SWC9 & 0.0129 & 0.4750 & 0.2255 & 0.2066 & 1.0000 & 1.0000 & 0.2862 & 0.7903 & 0.0337 \\
\hline SWC10 & 0.0875 & 0.4911 & 0.2252 & 0.0349 & 0.7421 & 0.7956 & 0.1959 & 0.7105 & 0.0169 \\
\hline SWC11 & 0.0374 & 0.0000 & 0.2246 & 0.0160 & 0.0000 & 0.9176 & 0.0000 & 0.5467 & 0.0307 \\
\hline SWC12 & 0.0638 & 0.4815 & 0.0533 & 0.1008 & 0.9341 & 0.6605 & 1.0000 & 1.0000 & 0.0000 \\
\hline SWC13 & 0.0209 & 0.4850 & 0.0319 & 0.1285 & 0.3015 & 0.7308 & 0.1540 & 0.7561 & 0.0135 \\
\hline SWC14 & 0.0000 & 0.3519 & 0.8515 & 1.0000 & 0.9281 & 0.8995 & 0.5381 & 0.9237 & 1.0000 \\
\hline SWC15 & 0.1227 & 0.4828 & 1.0000 & 0.0470 & 0.4443 & 0.8517 & 0.2118 & 0.8990 & 0.0055 \\
\hline SWC16 & 0.0426 & 0.3444 & 0.1171 & 0.0623 & 0.4499 & 0.7881 & 0.1528 & 0.7156 & 0.2405 \\
\hline SWC17 & 0.0110 & 0.4186 & 0.0103 & 0.1523 & 0.3819 & 0.8336 & 0.1735 & 0.6954 & 0.4693 \\
\hline SWC18 & 0.0525 & 0.4990 & 0.0000 & 0.0592 & 0.4628 & 0.7766 & 0.1833 & 0.7428 & 0.0228 \\
\hline
\end{tabular}

Table-A.9

\begin{tabular}{|c|c|c|c|c|c|c|c|c|c|}
\hline $\begin{array}{c}\text { Softwa } \\
\text { re } \\
\text { compa } \\
\text { ny }\end{array}$ & $\begin{array}{c}\text { Stockho } \\
\text { lders } \\
\text { equity } \\
\text { ratio } \\
\text { (FR1) }\end{array}$ & $\begin{array}{c}\text { Turnover rate } \\
\text { of accounts } \\
\text { receivables } \\
\text { (FR2) }\end{array}$ & $\begin{array}{c}\text { Turnover } \\
\text { rate of } \\
\text { inventory } \\
\text { (FR3) }\end{array}$ & $\begin{array}{c}\text { Return } \\
\text { of } \\
\text { stockhol } \\
\text { der } \\
\text { equity } \\
\text { (FR4) }\end{array}$ & $\begin{array}{c}\text { Quick } \\
\text { Ratio } \\
\text { (FR5) }\end{array}$ & $\begin{array}{c}\text { Operati } \\
\text { ng } \\
\text { income } \\
\text { ratio } \\
\text { (FR6) }\end{array}$ & $\begin{array}{c}\text { Operatin } \\
\text { g cash } \\
\text { flow ratio } \\
\text { (FR7) }\end{array}$ & $\begin{array}{c}\text { Return } \\
\text { of } \\
\text { Assets } \\
\text { (FR8) }\end{array}$ & $\begin{array}{c}\text { Marke } \\
\text { t Share } \\
\text { (FR9) }\end{array}$ \\
\hline SWC1 & 1.0000 & 0.4367 & 0.1232 & 0.0000 & 0.0000 & 0.2440 & 0.0976 & 0.1763 & 0.0046 \\
\hline SWC2 & 0.0059 & 0.5286 & 0.0149 & 0.2258 & 0.3548 & 0.4435 & 0.5098 & 0.7182 & 0.4009 \\
\hline SWC3 & 0.0163 & 0.5093 & 0.1658 & 0.0935 & 0.7730 & 0.6156 & 0.5434 & 0.6511 & 0.5789 \\
\hline SWC4 & 0.0179 & 0.3414 & 0.0066 & 0.0469 & 0.2818 & 0.0781 & 0.2138 & 0.3276 & 0.0243 \\
\hline SWC5 & 0.0195 & 0.5563 & 0.1655 & 0.0202 & 0.3097 & 0.0012 & 0.1680 & 0.1196 & 0.0008 \\
\hline SWC6 & 0.0655 & 0.4846 & 0.1656 & 0.0181 & 0.4448 & 0.1733 & 0.6199 & 0.4475 & 0.0406 \\
\hline SWC7 & 0.0369 & 1.0000 & 0.3203 & 0.0276 & 0.7379 & 0.2508 & 0.4892 & 0.3841 & 0.0477 \\
\hline SWC8 & 0.0316 & 0.4442 & 1.0000 & 0.0299 & 0.2990 & 0.2919 & 0.4344 & 0.3554 & 0.0199 \\
\hline SWC9 & 0.0071 & 0.4993 & 0.1654 & 0.2087 & 0.2654 & 1.0000 & 0.2948 & 0.7575 & 0.0337 \\
\hline SWC10 & 0.0443 & 0.5863 & 0.1657 & 0.0277 & 0.6408 & 0.2501 & 0.4409 & 0.4686 & 0.0205 \\
\hline SWC11 & 0.0190 & 0.0000 & 0.1652 & 0.0070 & 0.0226 & 0.7214 & 0.0000 & 0.0000 & 0.0231 \\
\hline SWC12 & 0.0329 & 0.4539 & 0.0409 & 0.0365 & 1.0000 & 0.0843 & 0.1965 & 0.4655 & 0.0000 \\
\hline SWC13 & 0.0094 & 0.4608 & 0.0535 & 0.1124 & 0.2504 & 0.0000 & 0.2477 & 0.4817 & 0.0162 \\
\hline SWC14 & 0.0000 & 0.4121 & 0.5970 & 1.0000 & 0.8633 & 0.6228 & 1.0000 & 1.0000 & 1.0000 \\
\hline SWC15 & 0.0573 & 0.4551 & 0.1657 & 0.0415 & 0.6123 & 0.4526 & 0.6252 & 0.9525 & 0.0066 \\
\hline SWC16 & 0.0207 & 0.4376 & 0.0609 & 0.0475 & 0.2975 & 0.2025 & 0.3561 & 0.3868 & 0.2440 \\
\hline SWC17 & 0.0056 & 0.4977 & 0.0094 & 0.1304 & 0.3001 & 0.3979 & 0.4148 & 0.3689 & 0.4679 \\
\hline SWC18 & 0.0263 & 0.4966 & 0.0000 & 0.0386 & 0.3839 & 0.1425 & 0.4013 & 0.3923 & 0.0220 \\
\hline
\end{tabular}

Table-A.10

\begin{tabular}{|c|c|c|c|c|c|c|c|c|c|}
\hline $\begin{array}{c}\text { Softwa } \\
\text { re } \\
\text { compa } \\
\text { ny }\end{array}$ & $\begin{array}{l}\text { Stockho } \\
\text { Iders } \\
\text { equity } \\
\text { ratio } \\
\text { (FR1) }\end{array}$ & $\begin{array}{l}\text { Turnover rate } \\
\text { of accounts } \\
\text { receivables } \\
\text { (FR2) }\end{array}$ & $\begin{array}{c}\text { Turnover } \\
\text { rate of } \\
\text { inventory } \\
\text { (FR3) }\end{array}$ & $\begin{array}{c}\text { Return } \\
\text { of } \\
\text { stockhol } \\
\text { der } \\
\text { equity } \\
\text { (FR4) }\end{array}$ & $\begin{array}{l}\text { Quick } \\
\text { Ratio } \\
\text { (FR5) }\end{array}$ & $\begin{array}{c}\text { Operati } \\
\text { ng } \\
\text { income } \\
\text { ratio } \\
\text { (FR6) }\end{array}$ & $\begin{array}{c}\text { Operatin } \\
\text { g cash } \\
\text { flow ratio } \\
\text { (FR7) }\end{array}$ & $\begin{array}{c}\text { Retur } \\
\text { n of } \\
\text { Assets } \\
\text { (FR8) }\end{array}$ & $\begin{array}{l}\text { Market } \\
\text { Share } \\
\text { (FR9) }\end{array}$ \\
\hline SWC1 & 1.0000 & 0.3886 & 0.1027 & 0.0050 & 0.0000 & 0.2062 & 0.0898 & $\begin{array}{c}0.201 \\
2 \\
\end{array}$ & 0.0040 \\
\hline SWC2 & 0.0040 & 0.5106 & 0.0182 & 0.2356 & 0.3529 & 0.4193 & 0.6025 & $\begin{array}{c}0.726 \\
1\end{array}$ & 0.4084 \\
\hline SWC3 & 0.0118 & 0.4966 & 0.1544 & 0.1132 & 0.6930 & 0.5735 & 0.6996 & $\begin{array}{c}0.796 \\
7\end{array}$ & 0.5711 \\
\hline SWC4 & 0.0121 & 0.3649 & 0.0088 & 0.0538 & 0.2772 & 0.0236 & 0.5398 & $\begin{array}{c}0.387 \\
9\end{array}$ & 0.0258 \\
\hline SWC5 & 0.0124 & 0.7631 & 0.1541 & 0.0482 & 0.3144 & 0.0910 & 0.2218 & $\begin{array}{c}0.353 \\
6\end{array}$ & 0.0026 \\
\hline SWC6 & 0.0417 & 0.5216 & 0.1541 & 0.0303 & 0.3923 & 0.1354 & 0.6201 & $\begin{array}{c}0.610 \\
5\end{array}$ & 0.0405 \\
\hline SWC7 & 0.0259 & 1.0000 & 0.1542 & 0.0366 & 0.5091 & 0.2226 & 0.5224 & $\begin{array}{c}0.491 \\
8\end{array}$ & 0.0493 \\
\hline SWC8 & 0.0211 & 0.5162 & 1.0000 & 0.0382 & 0.2589 & 0.2409 & 0.3353 & $\begin{array}{c}0.432 \\
0\end{array}$ & 0.0203 \\
\hline SWC9 & 0.0054 & 0.4554 & 0.1543 & 0.2181 & 0.6359 & 1.0000 & 0.7527 & $\begin{array}{c}0.826 \\
6\end{array}$ & 0.0328 \\
\hline
\end{tabular}


G. Anupama and V.V.S. Kesava Rao

\begin{tabular}{|c|c|c|c|c|c|c|c|c|c|}
\hline SWC10 & 0.0283 & 0.6071 & 0.1543 & 0.0344 & 0.6210 & 0.1974 & 0.6375 & $\begin{array}{c}0.497 \\
6\end{array}$ & 0.0206 \\
\hline SWC11 & 0.0127 & 0.0000 & 0.1538 & 0.0000 & 0.0121 & 0.6365 & 0.0000 & $\begin{array}{c}0.000 \\
0\end{array}$ & 0.0192 \\
\hline SWC12 & 0.0216 & 0.6230 & 0.1546 & 0.0402 & 1.0000 & 0.1436 & 0.5593 & $\begin{array}{c}0.463 \\
2 \\
\end{array}$ & 0.0000 \\
\hline SWC13 & 0.0067 & 0.4707 & 0.1540 & 0.1412 & 0.2521 & 0.0000 & 0.4388 & $\begin{array}{c}0.631 \\
8 \\
\end{array}$ & 0.0159 \\
\hline SWC14 & 0.0000 & 0.4454 & 0.4629 & 1.0000 & 0.7119 & 0.5557 & 1.0000 & $\begin{array}{c}0.963 \\
8\end{array}$ & 1.0000 \\
\hline SWC15 & 0.0641 & 0.4242 & 0.1543 & 0.0331 & 0.6317 & 0.5138 & 0.7646 & $\begin{array}{c}1.000 \\
0\end{array}$ & 0.0072 \\
\hline SWC16 & 0.0128 & 0.4487 & 0.0466 & 0.0680 & 0.2590 & 0.1926 & 0.3035 & $\begin{array}{c}0.512 \\
4\end{array}$ & 0.2469 \\
\hline SWC17 & 0.0099 & 0.5003 & 0.0116 & 0.0698 & 0.2635 & 0.3155 & 0.4198 & $\begin{array}{c}0.427 \\
7\end{array}$ & 0.4403 \\
\hline SWC18 & 0.0177 & 0.4611 & 0.0000 & 0.0442 & 0.3807 & 0.0762 & 0.2456 & $\begin{array}{c}0.432 \\
3\end{array}$ & 0.0212 \\
\hline
\end{tabular}

